\title{
Value-added effects of using aromatic plants in foods and human therapy
}

\author{
Birce MERCANOGLU TABAN ${ }^{1}$ (D), Elisaveth STAVROPOULOU ${ }^{2 *}$ (D), Lizziane KRETLI WINKELSTRÖTER ${ }^{3}$ (D), \\ Eugenia BEZIRTZOGLOU ${ }^{4}$ (D)
}

\begin{abstract}
Consumers' demands for low-processed and healthier food products led to a search for alternatives to replace or reduce synthetic food additives with natural ones. Aromatic plant derivatives which have GRAS status, have been examined for being natural food preservatives and antioxidants to prolong the shelf-life of foods. They contribute to food safety, owing to their anti-quorum sensing, and anti-biofilm properties. These potential food safety attributes and increasing demand for natural food additive options have led to an interest in the use of them, especially in traditional meat, dairy, and bakery products, which would provide them an added value, and increase the market competitiveness. Therefore, the overall perspective of the value-added effects of using aromatic plants and their derivatives in food production and of their incorporated use into packaging materials for active packaging are discussed in this review. In addition, it provides information on their antimicrobial and antioxidant actions. The review also aims to give detailed information on benefits of vegetal bioactive compounds in health and disease by giving their nutraceutical and health-promoting properties. The current knowledge on their application in the treatment of health disorders is presented, their ability to prevent diseases is discussed, and the areas for future research are proposed.
\end{abstract}

Keywords: aromatic plants; essential oils (EOs); natural bioactive compounds (BACs); antioxidant and antimicrobial activity; anti-biofilm; human therapy.

Practical Application: The value-added effects of aromatic plant derivatives permit us to understand their potential benefits to health. For instance, due to their unique characteristics such as anti-inflammatory, antioxidant, antimicrobial, and antiseptic properties, they should be of great importance in the food, pharmaceutical, and cosmetic industries. Yet, after classifying them as Generally Recognized as Safe (GRAS) they could be used as food ingredients to improve food quality and develop novel functional foods.

\section{Introduction}

Aromatic plants, also known as "herbs and spices", have been widely used for bactericidal, fungicidal, virucidal, antiparasitical, insecticidal, medicinal, cosmetic, agronomic, and sanitary applications since ancient times (Jamshidi-Kia et al., 2018; Tariq et al., 2019) and especially nowadays found more and more widespread use in food production as alternatives to potentially harmful synthetic food additives (Bakkali et al., 2008; Christaki et al., 2012). Furthermore, foodborne diseases are a growing public health problem worldwide, calling for more effective but safe, natural, and eco-friendly food preservation strategies (Hyldgaard et al., 2012). Besides, it is also observed that other food preservation strategies i.e., low-temperature preservation techniques like refrigeration, freezing, etc., and thermal preservation techniques like pasteurization and sterilization do not adequately control and solve the quality problems of perishable foods since they sometimes alter their status and cause adverse effects on their nutritional and sensory properties (Ortega-Ramirez et al., 2014; Singh, 2018). These foods require proper preservation to maintain their quality and safety. Hence, new antimicrobial and antioxidant delivery systems for foods and combination with other preservation technologies are needed to ensure food safety and overall quality of food products (Burt 2004; Filipčev, 2020; Mani-López et al., 2018). As an example, essential oils (EOs) of aromatic plants are applied as a part of a hurdle technology in which several food preservation factors are combined to provide microbial stability of the food products (Calo et al., 2015). For this reason, extracts and EOs of aromatic plants, with many originating from the Mediterranean area, found a great place as new-generation natural compounds in food production and human health with proven benefits (Demir et al., 2009; Christaki et al., 2012). Additionally, they have started to be used in animal nutrition as alternatives to antibiotics, especially after the ban of antibiotic feed additives within the European Union countries in 2006, to improve their productivity and hence the properties of the resulting animalderived foods (Christaki et al., 2012; Giannenas et al., 2013; Socaci et al., 2020). Besides, the use of antibiotics in animal feeds for prophylactic measures has raised concerns about the transmission and proliferation of multi-drug resistant bacteria through the food chain and led to an antibiotic-resistant crisis 
during the last decades (Pérez-Rodríguez \& Mercanoglu Taban, 2019). Although great efforts have been made to replace antibiotic feed additives in animal nutrition with aromatic plants, their use is still allowed with major restrictions in the USA (Gaucher et al., 2015) and similarly in Asian and Latin American countries, and Australia, but U.S. Food and Drug Administration (FDA) published new guidelines that exert pressure for a ban in the USA in near future (Bento et al., 2013; Giannenas et al., 2020).

According to the American Botanical Council (2019), the word "herb" indicates any aromatic plant material from temperate regions, used in minor quantities to flavor foods and beverages, but has little or no known nutritional value, whereas the word "spice" implies to aromatic plant material from tropical regions used in minor quantities to flavor foods and beverages, but has little or no known nutritional value, and the word "EOs" indicates the volatile oils that can be extracted from plants by distillation, solvents or expression.

The food industry has been undergoing innovative changes and development over the years. As a result of the application of new food processing techniques, new packaging methods, and new food ingredients and materials, new food products based on natural additives, previously considered as medicinal, become available on the market nowadays. Moreover, the food industry has noticed the benefits of using aromatic plant derivatives not only as flavor enhancers but also as natural preservatives which extends the shelf-life of their products (Campos et al., 2016; Fernandes et al., 2016; Antolak \& Kregiel, 2017). The improvement of nutraceutical properties of foods is also an expected beneficial effect of the inclusion of aromatic plant derivatives to foods and is closely associated with their health-promoting properties (Filipčev, 2020).

On the other hand, biofilms, which protect the microorganisms by allowing them to survive hostile environments and confer resistance to antibiotics, represent more than $80 \%$ of the microbial infections worldwide. Luckily, nature offers a wide range of aromatic plants that are capable of inhibiting QS mechanisms and biofilm formation (Olivero et al., 2011; Cáceres et al., 2020).

The present study aims to give an overall perspective of the value-added effects of using aromatic plants and their derivatives in food production and of incorporated use of them into packaging materials for active packaging. In addition, it provides information on their modes of biological action. The review also discusses the benefits of vegetal bioactive compounds in health and disease by giving their nutraceutical and health-promoting properties. The current knowledge on their application in the treatment of health disorders is presented, their ability to prevent diseases is discussed, and the areas for future research are proposed.

\section{The use of aromatic plant derivatives in food production}

In recent years there is an emerging demand of consumers for low-processed, safe, healthier, and with longer shelf-life food products containing natural food additives with the virtue of being generally recognized as safe (GRAS) (Smid \& Gorris, 1999; U.S. Food and Drug Administration, 2016; Laranjo et al., 2017), due to a growing concern on the use of synthetic food additives in food production (Kim et al., 2013; Alenisan et al., 2017; Socaci et al., 2020). Furthermore, World Health Organization (WHO) called for a worldwide reduction in the consumption of salt to reduce the incidence of cardiovascular diseases which ends with the need for other additives to maintain the safety of foods (Burt, 2004). Hence food industry is focused on finding natural compounds as an alternative to synthetic food additives to both meet the consumers' new demands and increase market competitiveness (Calo et al., 2015; Socaci et al., 2020).

On the other hand, EOs of several plants are started to be used as alternatives to synthetic fumigants for protecting the cereal grains against pest attacks, due to their pesticide properties. However, there is still a lack of data on the effectiveness of insecticides derived from aromatic plants under real field and storage conditions. Indeed, more studies are needed to be done on plant-derived repellents and their effectiveness before use in an integrated pest management system (Ebadollahi, 2013; Ningombam et al., 2017).

Medicinal plants are mainly known to be used in traditional and official medicine, whereas aromatic plants are used for their aroma and flavor (Giannenas et al., 2020). Although many studies in vitro have defined aromatic plants as effective antimicrobial and antioxidant compounds, their use in food products, such as traditional dairy, meat and, bakery products, represents an added value to these foods.

Aside from aromatic plants, medicinal plants have also been proposed as promising sources of natural food additives for the food industry (Ortega-Ramirez et al., 2014). Therefore, aromatic plants and their various extracts and EOs are started to be used mostly in minimally processed food, organic food, and functional food production since they are abundant and cost-effective sources of natural antimicrobials, antioxidants, and natural bioactive compounds (BACs) with proven health benefits when incorporated in food formulations (Filipčev, 2020) (Figure 1). Moreover, they are used to replace synthetic preservatives and antioxidants which help to increase physiological functionality and storage stability of foods (Atarés \& Chiralt, 2016; Laranjo et al., 2017). They should also not impair the sensory acceptance of the foods to which they are added. As an example, Tohma \& Turan (2015) showed that the use of rosemary extracts extends the usage life of hazelnut oil for frying, without having any adverse effect on the sensory acceptability of French fries.

A few preservatives containing EOs are already commercially available. "DMC Base Natural" includes 50\% EOs from citrus, rosemary (Rosmarinus officinalis L.), sage and, 50\% glycerol, "Protecta One" and "Protecta Two" are mixtures of herb extracts used as food additives in the USA (Burt, 2004).

Aromatic plants can be added to food production either in a fresh or dried state or in the form of their derivatives such as extracts and EOs. However, there are some restrictions on the immediate inclusion of EOs into foods, such as their intense aroma and lack of reproducibility of their activity due to variable biological effectiveness of qualitative and quantitative changes in the content of bioactive components that they contain (RibeiroSantos et al., 2017). As an example, Li et al. (2013) showed the morphology variations and the accumulation of EOs of Cinnamomum 


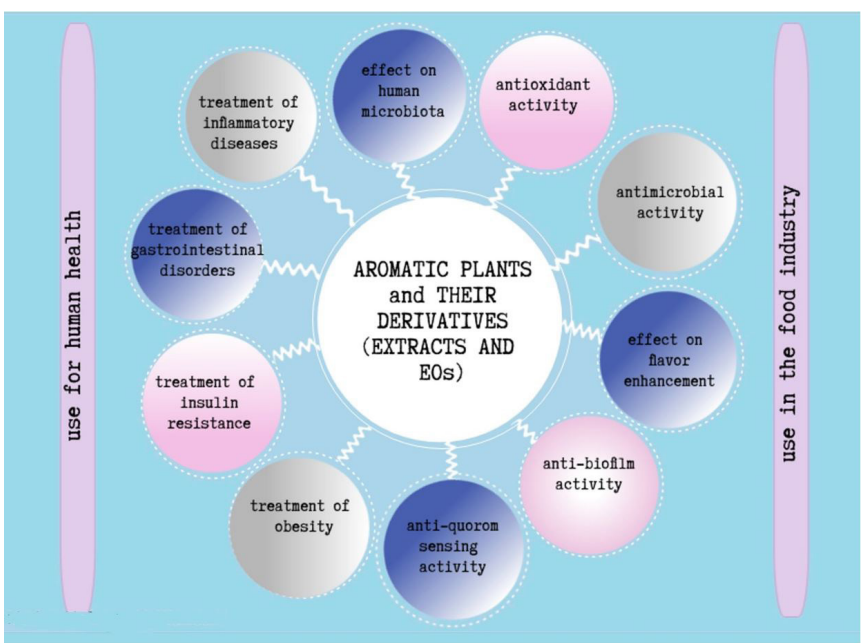

Figure 1. Value-added effects of using aromatic plants and their derivatives in foods and human therapy.

cassia at different developmental stages of the oil cells within the same leaf blade. Further, the extrapolation of results from in vitro experiments with laboratory media into food products is not straightforward, as food is a complex system composed of different interconnected microenvironments (Singh Negi, 2012). Besides, their low water solubility and high volatility features make them difficult for some food applications (FernándezLópez \& Viuda-Martos, 2018). Therefore, their direct addition to foods causes rapid degradation due to the interaction between their unstable, volatile composition and external factors such as light, oxidation, and heating (Sharma et al., 2021). However, an appropriate selection of EOs depending on the type of food can hinder these undesirable effects (Burt, 2004). In addition, nanoencapsulation of EOs in polymers of biodegradable and edible coatings represents a useful technique for masking their odor and flavor and for preventing their evaporation, and also for preventing damage caused by the interactions of the hydrophobic constituents of EOs with the food matrix (Alizadeh et al., 2021; Carpena et al., 2021). In other words, EOs are added into foods preferentially as nanoemulsions or encapsulated in edible and biodegradable polymers are used in active packaging (AP) systems, to overcome the formation of an intense aroma due to their strong odor during their direct addition to foods (Hyldgaard et al., 2012; Fernández-López \&Viuda-Martos, 2018).

\section{Bioactive compounds (BACs) of aromatic plant derivatives and their modes of biological action}

Nowadays seeking new natural compounds for food preservation to reduce or replace the use of chemical additives becomes a major trend worldwide. For this approach, using aromatic plant extracts and EOs in food production is considered as an important factor for food quality and safety, due to the prevention of many aggravating factors like microbial spoilage and oxidation, besides leading to the strengthening of taste and color of food (Magnuson et al., 2013; Fernandes et al., 2016; Mani-López et al., 2018).
Today, around 3000 EOs have been produced by using at least 2000 plant species, out of which 300 are important from the commercial point of view (Raut \& Karuppayil, 2014; Tariq et al., 2019). They contain BACs of different composition and activity, which are secondary metabolites of aromatic plants that are generally localized in temperate to warm countries like the Mediterranean and tropical countries (Bakkali et al., 2008; Amorati et al., 2013), such as terpenes, terpenoids, and sesquiterpene hydrocarbons, and their oxygen-substituted derivatives as volatile compounds, and hydrocarbons, sterols, fatty acids, waxes, carotenoids, and flavonoids/flavanols as nonvolatile residues (Christaki et al., 2012; Calo et al., 2015; Shahidi \& Ambigaipalan, 2015; Hashemi et al., 2017; Giacometti et al., 2018). They can be synthesized by all plant organs, such as seeds, roots, twigs, barks, leaves, buds, flowers, fruit peels. They are stored in secretory cells, canals, epidermic cells, or glandular trichomes, but their qualitative and quantitative composition which determines their antioxidative and antimicrobial potential, is dependent on what part of the plants are used (Bakkali et al., 2008; Fisher \& Phillips, 2008; Calo et al., 2015; Nazzaro et al., 2017; Mani-López et al., 2018; Sharma et al., 2021) and on the selection of suitable extraction procedure since the amount of EOs can vary from 0.01 to $10 \%$ of the total mass of the aromatic plants (Elshafie \& Camele, 2017; Hashemi et al., 2017). As an example, Kuropka et al. (1991) showed that terpenes were found in very small amounts in EOs from green parts and roots, while high amounts were found in EOs from flowers in sneezewort (Achillea ptarmica). On the other hand, EOs of citrus are mainly located in the fruit peel which facilitates their extraction more economically way since the fruit peel constitutes a waste for the fruit juice industry (Settanni et al., 2012). In addition, since the extraction step plays a prime role in the performance and also in the quality of EOs, novel extraction techniques (supercritical fluid extraction, microwave-assisted extraction, ultrasoundassisted extraction, molecular spinning band distillation, dynamic headspace, static headspace, solvent flavor evaporation, etc.) that can overcome the drawbacks of the steam distillation, such as the degradation of some volatile heat-sensitive compounds of EOs due to their relatively high temperatures and long extraction times to obtain high-quality EOs without damage or alteration of their thermosensitive components (Tongnuanchan \& Benjakul, 2014; Elshafie \& Camele 2017; Hashemi et al., 2017; Pateiro et al., 2018).

Natural BACs of aromatic plants have been studied for years due to their unique characteristics that carry crucial importance in food production (Fernandes et al., 2016). Much interest is focused on the Lamiaceae family that consists of roughly 236 genera and 7200 species, such as rosemary, sage, thyme, and oregano, plants of high commercial importance (Hashemi et al., 2017). As an example, rosemary which belongs to the Lamiaceae family, is a widely fresh or dried-consumed aromatic plant and its extracts include various BACs such as carnosol, carnosic acid, caffeic acid, rosmanol, and rosmarinic acid (Ribeiro-Santos et al., 2015). Its EOs include $\alpha$-pinene, (-)-bornyl acetate, camphor and eucalyptol (Arranz et al., 2015), which produce a synergic effect when combined with others EOs or compounds (Gibriel et al., 2013; Camele et al., 2019). They are used in traditional food production as flavoring agents, are 
incorporated in food packaging as antimicrobial and antioxidant agents, and in folk medicine due to its anti-cancer and antiinflammatory effects (Teixeira et al., 2013; Ribeiro-Santos et al., 2015). Sage (Salvia officinalis), mint (Mentha piperita), marjoram (Marjorana hortensis Moench), oregano compactum (Origanum compactum), and thyme (T. vulgaris) which belong to the family of Lamiaceae, are also other aromatic plants with significant interests in the food industry (Lorenzo et al., 2019). Among them, thyme includes thymol, carvacrol, geraniol, and linalool which are reported to have antioxidant and antimicrobial effects (Fachini-Queiroz et al., 2012; Borugă et al., 2014; Laranjo et al., 2019). Oregano includes carvacrol (30\%) and thymols (27\%) as the major chemical components, whereas linalool is the major component in cilantro (Coriandrum sativum), and other EOs such as $\alpha$, and $\beta, a$ - and $b$-thuyone (57\%), and camphor (24\%) are present at high levels in wormwoot (Artemisia herba alba) (Bhavaniramya et al., 2019). Therefore, leaves and EOs of thyme are used in various industrial food products such as ice-cream, butter, meat, liqueur, and candy not only for flavor enhancement but also for slowing the oxidation process and decreasing color changes of these products (Laranjo et al., 2019; Lorenzo et al., 2019) as well as for improving their shelf-life by its antimicrobial feature (Dauqan \& Abdullah, 2017). EOs of eucalyptus (Eucalyptus globulus) include 1,8-cineole as the major compound and have other BACs such as cryptone, $\alpha$-pinene, $p$-cymene, $\alpha$-terpineol, trans-pinocarveol, phellandral, cuminal, globulol, limonene, aromadendrene, spathulenol, and terpinene-4-ol which can be used as flavoring agents and natural preservatives in especially candy production (Sebei et al., 2015). The largest sector of the world's EOs production is on citrus Eos (Tirado et al., 1995) which are also used as a flavoring and antioxidant agents in food production.

The use of aromatic plant derivatives as natural food preservatives requires detailed knowledge about their properties, such as BACs, the range of target microorganisms, the minimum inhibitory concentration (MIC), the mode of biological action, and the effect of food matrix components on their preservative properties (Hyldgaard et al., 2012). In other words, it is important to develop a better understanding of modes of biological action of aromatic plant extracts and EOs for the applications in food production and human health (Bakkali et al., 2008). However, predictions about the mode of action of EOs require several investigations of target sites of their BACs, and their interactions with the surrounding environment (Hyldgaard et al., 2012). Table 1 lists the selected publications and their main results regarding the major BACs of some aromatic plants used in the food industry and their antimicrobial and antioxidant activities. On the other hand, to the knowledge, that many different methods have been compiled to evaluate the antioxidant and antimicrobial performance of EOs in the literature and those that have sometimes given contradictory results that may mislead future research, it becomes not easy to compare the efficiency of EOs.

BACs of aromatic plants possess antioxidant properties not only for protecting the cellular systems from oxidative damage and reduce the risk of chronic diseases including cancer, cardiovascular disease, diabetes, and Alzheimer's in humans but also for delaying the development of off-flavor in food products by inhibiting oxidative rancidity (Fernandes et al., 2016). Shahidi \& Ambigaipalan (2015) reported that the antioxidant effect of EOs is due to the presence of hydroxyl groups in their phenolic compounds. Besides, Ruberto \& Baratta (2000) analyzed the antioxidant effectiveness of almost one hundred components of EOs of fresh leaves of Lippia origanoides Kunth. and M. spicata L. by measuring the formation of hydroperoxydienes and malondialdehyde components of the oxidative process of a lipid matrix and found that two phenols (carvacrol and thymol) were the most active ones among the other volatile compounds. In other words, the antioxidant activity of BACs is closely correlated with their phenolic compounds and mainly due to the tendency of phenolic compounds to inhibit the synthesis of reactive oxygen species and their high redox properties. It also depends on their chemical structure, which may be in charge of chelating transition metals (binding of transition metal ion catalysts), neutralizing free radicals, and quenching singlet and triplet oxygen by delocalization or decomposing peroxides and hence play a protective role for highly unsaturated lipids in foods against oxidative damage (Christaki et al., 2012; Tongnuanchan \& Benjakul, 2014; Alizadeh et al., 2021). Phenolic compounds of EOs, such as the monoterpenes carvacrol, the phenylpropene eugenol, and thymol can be stated as primary antioxidants or chain-breaking antioxidants, and effective free radical scavengers (Bakkali et al., 2008). Their antioxidant activity occurs through start-up, diffusion, and termination phases in which the start-up phase involves homolytic breakdown of hydrogen at $\alpha$-position relative concerning the double fatty acid chain bond, leading to the formation of allyl radical, the propagation phase involves oxidizing of the unsaturated fatty acids by formed peroxyl radicals, yet leading to the production of hydroperoxides, and the termination phase involves decomposition of these hydroperoxides, originating alcohols, hydrocarbons, formic acid, aldehydes, ketones, alkyl formates, and alkoxyl radicals (Miguel, 2010; Pateiro et al., 2018). The reactions in the amplification phase cause a chain reaction until a termination phase occurs (Shahidi \& Ambigaipalan, 2015).

Functional properties of BACs are usually determined by their chemical composition, but their bioaccessibility and bioavailability aspects as well as their metabolic fates are of great importance for developing novel functional foods (Lorenzo et al., 2019).

Aromatic plant derivatives are potent inhibitors of bacterial growth in foods and most of their properties have been linked to EOs and other secondary plant metabolites (Calo et al., 2015). Different types of EOs include lavender (Lavandula angustifolia), thyme (Thymus vulgaris), eucalyptus (Eucalyptus globulus), cinnamon (Cinnamomum zeylanicum), neem (Azadirachta indica), clove (Syzygium aromaticum), peppermint (Mentha piperita), lemon (Citrus limonum), tea tree (Melaleuca alternifolia), mustard (Brassica nigra), fennel (Foeniculum vulgare), and others (Bhavaniramya et al., 2019; Laranjo et al., 2019; Tariq et al., 2019). These volatile compounds are referred to as biologically active substances, implying their effect on living organisms, and are responsible for controlling microbial growth and preserving food. Therefore, the antimicrobial effects of EOs have been screened against various microorganisms for years, but their mechanisms of action have still not been completely understood due to the various BACs of EOs as mentioned (Calo et al., 


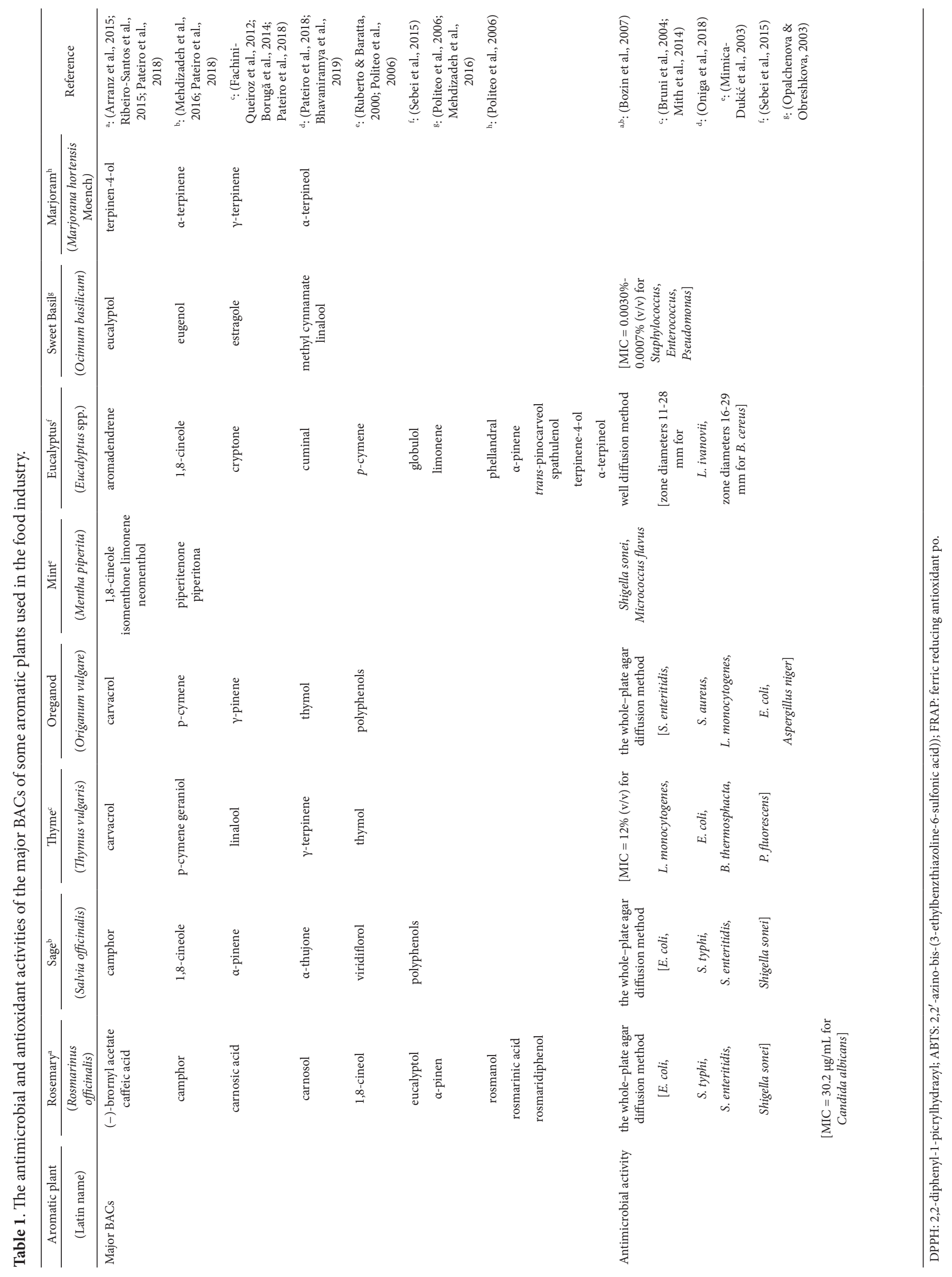



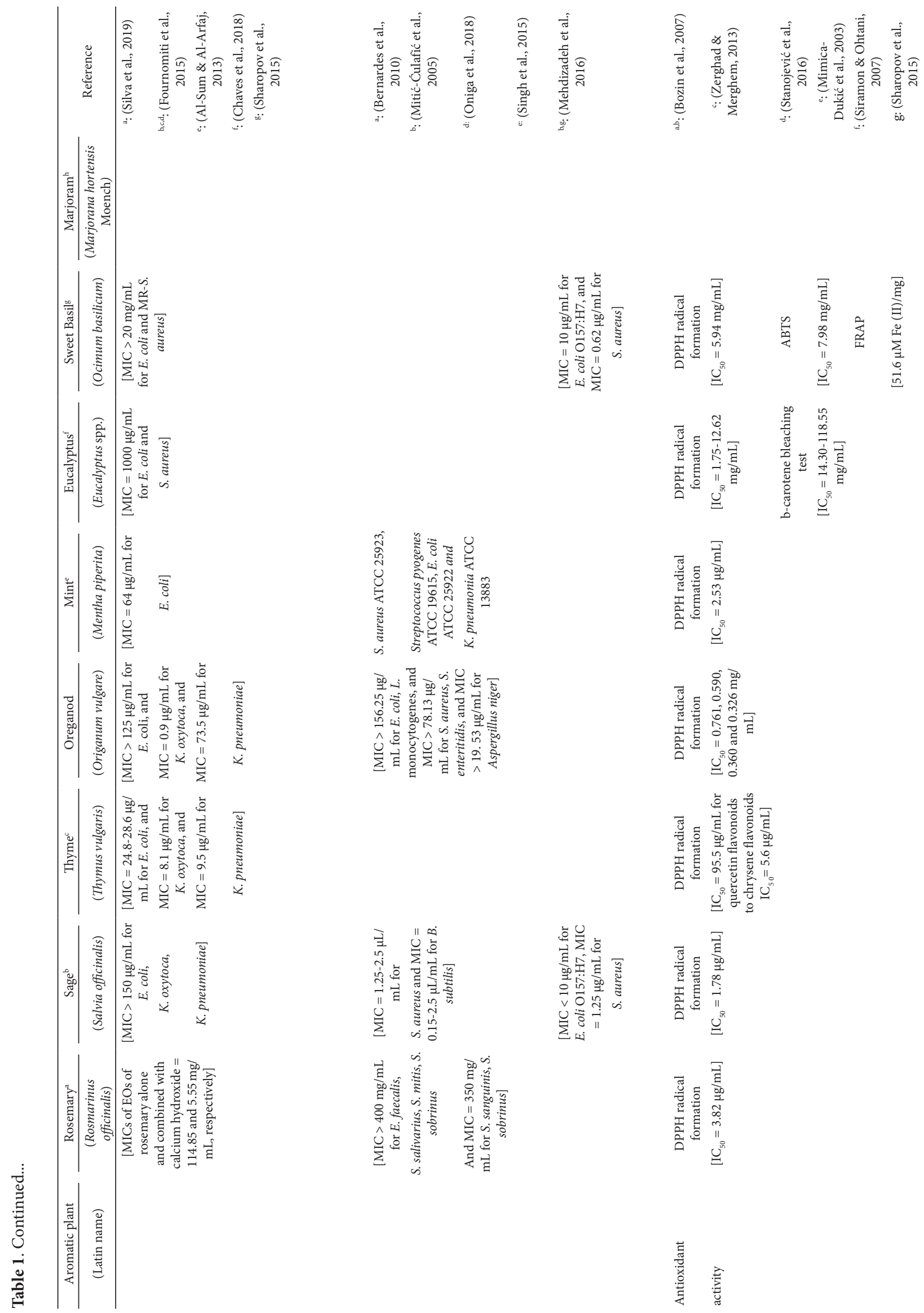

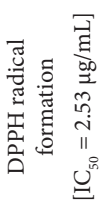
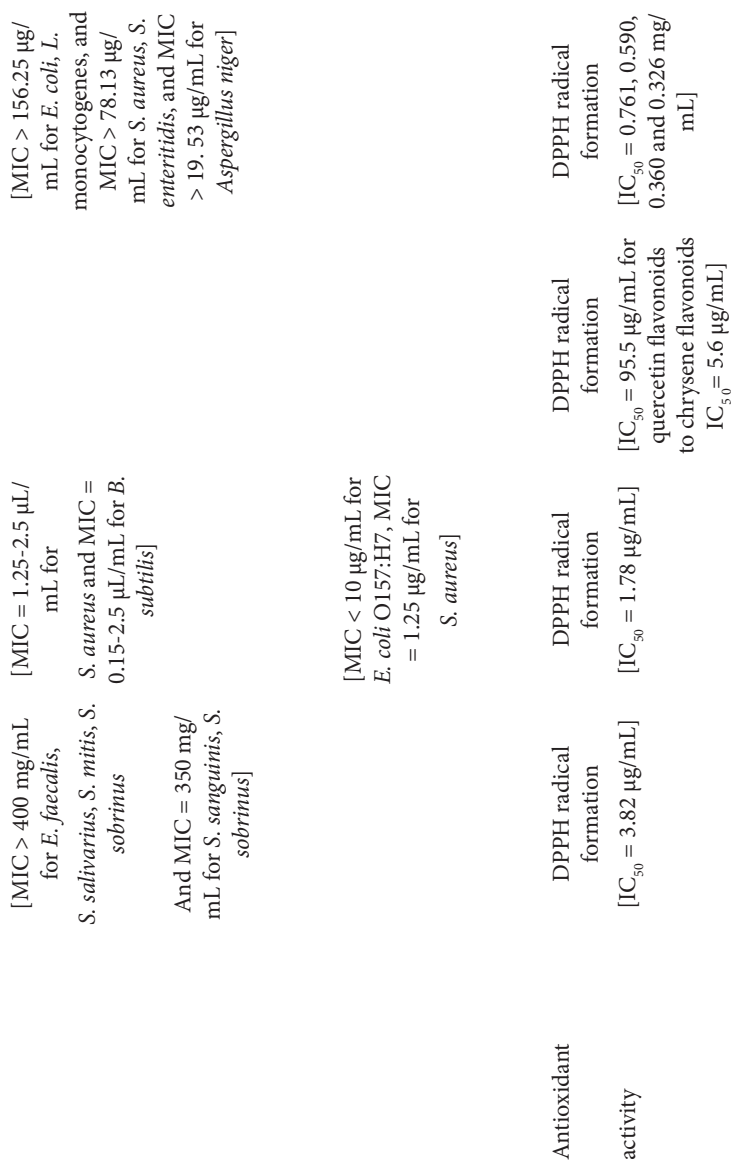


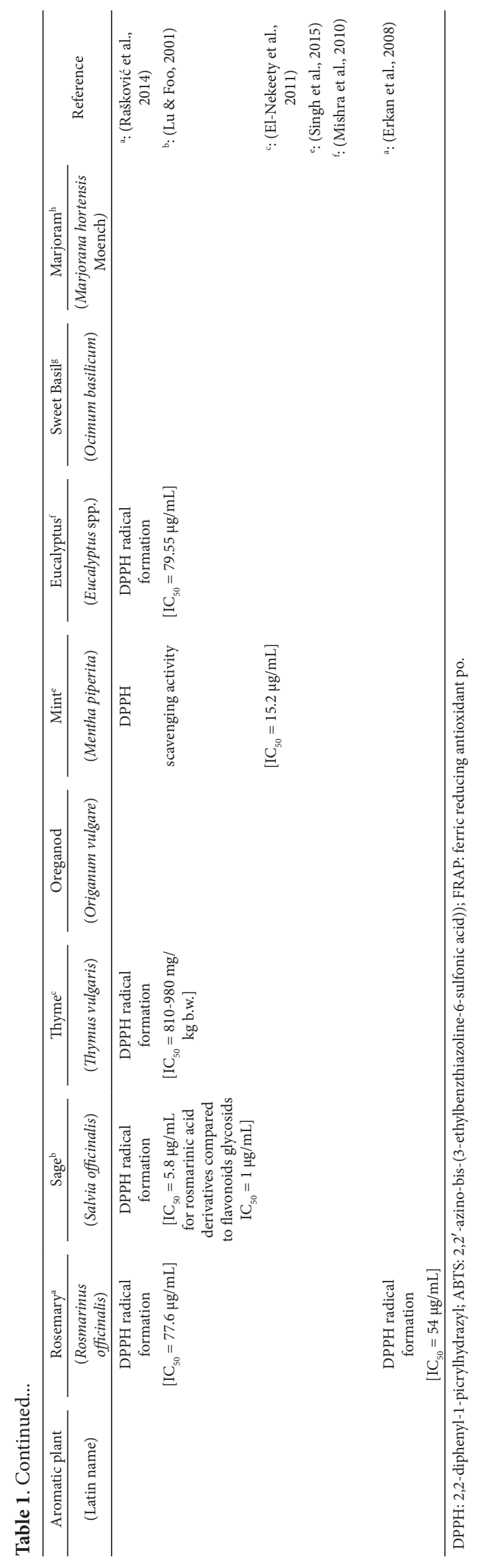


2015; Bhavaniramya et al., 2019). However, it is known that the hydrophobicity of BACs of EOs enables them to accumulate in the lipid bilayer of the bacterial cell membrane and mitochondria, which leads to more permeable cells and this leads to disruption of cell homeostasis, extensive leakage of critical molecules from bacterial cells, growth inhibition, and cell death (SolórzanoSantos \& Miranda-Novales, 2012). In addition, the aromaticity and the presence of the functional hydroxyl group attached to a phenyl ring in phenolic compounds are also attributed to the greatest antibacterial activity among the secondary metabolites found in EOs (Christaki et al., 2012). Gram-positive bacteria cell wall contains peptidoglycan with proteins and teichoic acid attached to it, which provides EOs that easily pass across this membrane and reach cytoplasm. Unlike the cell wall of Grampositive bacteria, the outer membrane of Gram-negative bacteria contains hydrophilic lipopolysaccharides (LPS), which create a barrier toward macromolecules and hydrophobic compounds, providing Gram-negative bacteria with higher tolerance toward hydrophobic EOs. Hence, Gram-negative bacteria are less susceptible to EOs than Gram-positive bacteria (Trombetta et al., 2005; Mishra et al., 2020). Mishra et al. (2020) also stated the effect of the shape of bacteria on the action of EOs and reported that rod-shaped cells are additionally vulnerable as compared to coccoid shape ones.

\subsection{Antimicrobial effect of aromatic plant derivatives against pathogenic microorganisms in foods (natural preservatives)}

The chemical composition of EOs is very complex because hundreds to thousands of components may be observed within a single EO. Since the biological activity of EOs depends on the whole phytocomplex, it is not appropriate to try to detect a single compound as responsible for the activity (Buriani et al., 2020). However, the antimicrobial activity of most EOs may be represented by few major compounds that nearly constitute $20-70 \%$ in comparison to other components of oil fraction (Bhavaniramya et al., 2019; Tariq et al., 2019). In addition, the composition of each EO can vary depending on the season of harvest, and the methods used to extract the oil (Hyldgaard et al., 2012). As an example, the minimum inhibitory concentrations (MICs) of four different types of thyme oil (thymol, carvacrol, thuyanol, and linalool type) against $S$. aureus were found between 250 and $4000 \mu \mathrm{g} / \mathrm{mL}$ depending on the presence of thymol (Elshafie \& Camele, 2017). Therefore, their antimicrobial activity cannot be confirmed based only on the action of one compound (Bajpai et al., 2012).

As mentioned before, the antimicrobial activity of EOs can be due to their ability to penetrate through bacterial membranes to the interior of the cell and exhibit inhibitory activity upon the functional properties of the cell, and to their lipophilic properties. In other words, they primarily act by enhancing the permeability of the membrane (Mishra et al., 2020).

Most studies on the antimicrobial effect of EOs have been mostly performed on bacteria, however many kinds of EOs obtained from different aromatic plants were also shown to exhibit intense antifungal properties (Prakash et al., 2012; Calo et al., 2015; Nazzaro et al., 2017; Alizadeh et al., 2021). As an example,
Hu et al. (2017) showed a 93.41\% reduction in the growth of Aspergillus flavus mycelia at a concentration of $8 \mu \mathrm{L} / \mathrm{mL}$ of EOs of turmeric (Curcuma longa L.) in Yeast Extract Sucrose broth. On the other hand, many EOs were also tested for antiviral activity against various viruses, such as DNA virus: human Herpes virus type 1 and 2 (HSV-1 and HSV-2) [74], and RNA virus: SARS-CoV and Junin virus (Miguel, 2010). Yasmin et al. (2020) also reported the list of several aromatic plant extracts which act as antiviral agents against viral diseases of livestock. Furthermore, studies of plant extracts against the virus have been carried showing their antiviral action (Boukhatem \& Setzer, 2020) by inhibiting in vivo and in vitro viral replication (Notka et al., 2004; Ganesan et al., 2012). For example, Lycoris radiata, Pyrrosia lingua, Artemisia annua, and Lindera aggregate showed promising antiviral effects (Boukhatem \& Setzer, 2020). Amaryllidaceae species contain lycorine which showed a potent effect upon SARS-CoV (Boukhatem \& Setzer, 2020), but also upon Herpes simplex virus (HSV, type I) (Renard-Nozaki et al., 1989) and Poliomyelitis virus (Ieven et al., 1982). Yet, the root extract of Potentilla arguta blocked Respiratory syncytial virus (RSV) (Boukhatem \& Setzer, 2020). Recently, this research was extrapolated to SARS-CoV-2 as the virus belongs to the same family and presents similarities (Boukhatem \& Setzer, 2020).

Tariq et al. (2019) showed the chemical composition of various EOs of aromatic plants and their antibacterial activity on several pathogenic bacteria. For example, juniper (Juniperus phoenicea) has an inhibitory effect on $P$. aeruginosa, Escherichia coli, S. aureus, Enterococcus faecium, Salmonella enterica spp., and ajwain (Trachyspermum ammi) on S. aureus, E. coli, and Klebsiella pneumoniae. Calo et al. (2015) also gave detailed information on antibacterial and antifungal activities of EOs of aromatic plants against human pathogens. Fournomiti et al. (2015) also showed antimicrobial activities of oregano, sage, and thyme against E. coli, K. oxytoca, and K. pneumoniae. EOs of basil (Ocimum basilicum) has been shown to have an antimicrobial effect against multi-drug resistant strains of the genera Staphylococcus, Enterococcus, and Pseudomonas when they are exposed for $24 \mathrm{~h}$ at a minimum inhibitory concentration (MIC) between $0.0030 \%$ and $0.0007 \%$ (v/v) (Opalchenova and Obreshkova 2003). EOs of thyme (T. vulgaris) is effective at a MIC of $0.12(\mathrm{mg} / \mathrm{mL})$ for S. aureus subsp. aureus, Enterococcus faecalis, and E. coli, and of $0.24(\mathrm{mg} / \mathrm{mL})$ for P. aeruginosa determined by employing the standard disks diffusion technique (Bruni et al. 2004). EOs of cinnamon, oregano, and thyme showed significant antimicrobial activities with $\mathrm{MIC} \geq 0.125 \mu \mathrm{L} / \mathrm{mL}$ against Listeria monocytogenes, E. coli, Bacillus thermosphacta, and Pseudomonas fluorescens by using the broth dilution method (Mith et al., 2014), whereas Demo et al. (2005) did not find any inhibition on $P$. aeruginosa by using the disk diffusion method with any of the EOs of aromatic plants like Aloysia triphylla, Psila spartoides, Baccharis flabellate, Pectis odorata, P. spartoides, etc. collected from different regions of Argentina. However, they found $A$. triphylla., P. spartoides, and Anemia tomentosa as the most effective compounds against Bacillus cereus, while A. triphylla and $B$. flabellate against $S$. aureus. Habbadi et al. (2018) found $O$. compactum and T. vulgaris as the most significant in vitro antibacterial activities, with a MIC of 0.156 and $0.312 \mathrm{mg} / \mathrm{mL}$, on Allorhizobium (Agrobacterium) vitis respectively. As another 
example, Settanni et al. (2012) showed strong inhibitory activities of monoterpenes, sesquiterpenes, and oxygenated derivatives in several citrus genotypes' (grapefruit, orange, mandarin, pummelo, kumquat, and lemon) EOs against 43 strains of $L$. monocytogenes, 35 strains of $S$. aureus, and 14 strains of $S$. enterica spp. The terpenes and the oxygenated terpenes in EOs of lemon showed significant antifungal potential against Candida spp. such as C. albicans, C. tropicalis, and C. glabrata (Bhavaniramya et al., 2019). Sartoratto et al. (2004) studied antimicrobial activities of EOs of Mentha piperita, M. spicata, T. vulgaris, Origanum vulgare, O. applii, A. triphylla, Ocimum gratissimum, and O. basilicum and found that $A$. triphylla and $O$. basilicum had moderate inhibition activity against $S$. aureus while only $A$. tryphila and M. piperita were able to control the yeast Candida albicans. Unlu et al. (2010) reported the EOs of cinnamon as inhibitory agents on the diverse range of bacterial pathogens, such as $E$. feacium, Streptococcus pyogenes, $S$. aureus, S. pneumoniae, $B$. cereus, E. faecalis, Acinetobacter Iwoffi, K. pneumonia, E. coli, S. Typhimurium, Proteus mirabilis, Mycobacterium smegmatis, $P$. aeruginosa, and Clostridium perfringens, using disc diffusion and minimum inhibitory concentration methods.

The use of synthetic compounds for food preservation may tend to undesirable aspects, including acute toxicity, teratogenicity, carcinogenicity, and slow degradation periods, which could also lead to environmental problems, such as pollution (Faleiro, 2011). EOs, as being natural antimicrobials (substances that are naturally occurring and directly derived from biological systems without alteration or modification in a laboratory setting are recognized as "natural antimicrobials") (Calo et al., 2015), are good alternatives that are effective in several food applications by decreasing growth and survival of microorganisms (Burt, 2004; Fisher \& Phillips, 2008; Juneja et al., 2012; Solórzano-Santos \& Miranda-Novales, 2012; Jayasena \& Jo, 2013; Mishra et al., 2020). To the knowledge, a higher dose of EOs is needed for effective antimicrobial action in foods than that observed in in vitro assays since foods are multicomponent systems consisting of different interconnecting microenvironments (Filipčev, 2020). The lipid percentage of traditional meat and dairy products are considerably high and EOs are soluble in lipids, which taken together with the usual low $\mathrm{pH}$ and the typical low $\mathrm{a}_{\mathrm{w}}$ that reduces the aqueous phase of these products increasing the contact between EOs and foodborne or spoilage microorganisms, enhances their antimicrobial effect (Calo et al., 2015). Besides, most of the BACs of EOs show synergistic antimicrobial activity when used in combination (Bassolé \& Juliani, 2012). As an example, some BACs such as $\gamma$-terpinene, carvacrol, and $\mathrm{p}$-cymene are more effective when they are combined. Because p-cymene acts as a mediator for transportation of carvacrol across cell wall components and the cytoplasmic membrane of pathogenic fungi. In addition, the enzymatic reactions within the EOs and the lipophilic properties of BACs can play a role in degrading the microbe plasma membrane, leading to the lyses of the hypha wall in fungi (Elshafie \& Camele, 2017).

The antimicrobial effect of EOs can also be increased when used in combination with other technologies for food preservation. For example, although antimicrobial activity tests demonstrated the effectiveness of Laurus nobilis and Myrtus communis EOs, which were all obtained by steam distillation from aerial parts
L. nobilis and M. communis from Morocco, low concentrations $(0.2 \mathrm{~mL} / \mathrm{mL})$ of these EOs combined with mild heat treatment (at $54^{\circ} \mathrm{C}$ for $10 \mathrm{~min}$.) or high hydrostatic pressure (HHP) (175$400 \mathrm{MPa}$ for $20 \mathrm{~min}$ ) treatments showed synergistic lethal effects against E. coli O157:H7 and L. monocytogenes cells in the tubes containing $5 \mathrm{~mL}$ of sterile citrate-phosphate buffer at $\mathrm{pH} 7.0$ or 4.0, allowing up to $5 \mathrm{log}$ inactivation of bacteria counted by image analyzer automatic counter (Cherrat et al., 2014).

\subsection{Antioxidant effect of aromatic plant derivatives in food products}

The shelf life in certain foods is drastically reduced if no additives are added. Animal-derived foods are the best examples of perishable food products with different lipid and protein amounts (Domínguez et al., 2018). Lipid and protein oxidation is the main reason for the chemical spoilage in animal-derived foods that leads to the production of objectionable changes in nutritional value, flavor, and texture of foods. Although milk contains trace amounts of antioxidant molecules such as low molecular weight (LWM) thiols (Niero et al., 2015), ascorbate (Nielsen et al., 2001), tocopherol, retinol, and carotenoids (Jensen \& Nielsen, 1996), enzymes (superoxide dismutase, catalase, and glutathione peroxidase) (Khan et al., 2019), and dairy products have potential antioxidant activity due to their wide diversity of antioxidant molecules such as milk caseins (phosphate provides antioxidant activity to the casein micelles) and whey proteins (Alenisan et al., 2017), they are not enough to prevent lipid oxidation and so to neutralize and to scavenge the free radicals and their harmful effects. Therefore, dairy products are still highly perishable foods that are susceptible to hydrolytic and oxidative rancidity and deteriorate when they are exposed to heat, oxygen, light, enzymes, and metal ions (Filipčev, 2020).

As within milk and dairy products, meat and meat products are also rich in protein and lipids which can be oxidatively degraded as a result of chemical and enzymatic processes during production and storage. Pro-oxidants that can be found in meat products include reactive oxygen species (ROS), reactive nitrogen species (RNS), and byproducts of oxidative processes (Oswell et al., 2018). In addition, the presence of transition metals, such as heme iron, in meat and meat products greatly contributes to the oxidation process which results in the loss of organoleptic and nutritional properties in these foods (Jayasena \& Jo, 2013; Macho-González et al., 2020). Lipid oxidation is initiated and propagated by a free-radical chain reaction. On the other hand, protein oxidation occurs at the side chain of amino acids (tryptophan, cysteine, histidine, methionine, and tyrosine) that have high electron density as well as the protein backbone (Papuc et al., 2017). During oxidation reactions, the formation of hydroperoxides promotes new degradation reactions and generates undesirable volatile compounds, such as ketones, aldehydes, alcohols, and acids (Lorenzo et al., 2018). In other words, meat and meat products are also highly susceptible to lipid and protein oxidation due to their high contents of polyunsaturated fatty acids and prooxidants such as heme species. Therefore, oxidation negatively affects not only the appearance of meat and meat products by oxidizing myoglobin to oxymyoglobin and metmyoglobin, and producing brown pigments that also 
reduces consumer satisfaction (Pateiro et al., 2018) but also the digestibility of key nutrients (Oswell et al., 2018). It also yields genotoxic and cytotoxic derivatives of amino acids (Papuc et al., 2017). Unlike milk, meat and meat products are lacking various endogenous antioxidants (Filipčev, 2020).

Bread and bakery products can be improved in nutrient profile and functionality by supplementing their formulation with bioactive substances and antioxidants. As an example, Dziki et al. (2014) reported an improved antioxidant activity of loaves of bread when they were supplemented with turmeric (Curcuma longa), cilantro, fennel, ginger (Zingiber officinale), oregano, and black and green tea (Camellia spp.) extracts. Filipčev (2020) also listed other important attributes such as color, taste, odor, volume, and texture of bread and bakery products when they were supplemented with various aromatic plant derivatives such as extracts of black or green tea and green coffee, EOs of oregano, ginger, fennel, coriander, turmeric, and herbal blends of nettle, rosehip, ironwort, etc., besides their antioxidative and pro-health potential.

Antioxidants are compounds capable of slowing or retarding the oxidation of oxidizable nutrient elements such as lipids, proteins, carbohydrates, and to a minor extent, other organic molecules found in foods, even when used in $<1 \%$ amounts as compared to the amount of material they have to protect (Amorati et al., 2013).

Owing to excellent antioxidant properties, aromatic plant extracts and EOs can be used as a means to control and prevent lipid and protein oxidation during storage under ambient conditions or refrigerated state and hence to prolong shelflife of dairy, meat, and bakery products (Amorati et al., 2013; Filipčev, 2020; Mishra et al., 2020). As an example, rosemary extract, which is allowed as a component of an antioxidant blend in FSIS Directive 7120.1, 'Safe and suitable ingredients used in the production of meat, poultry, and egg products, is the most prevalent antioxidant replacer used throughout the meat industry (Oswell et al., 2018). Some synthetic antioxidants such as butylated hydroxyanisole (BHA), butylated hydroxytoluene (BHT), tertiary butyl hydroxyquinone (TBHQ), and sodium erythorbate which are mainly used to solve the problem of oxidative decay in meat products, are suspected to be potentially harmful to human health. Therefore, in several countries, their use has been limited or even prohibited. Besides, the level of these antioxidants is critical in preserving lipid-containing foods to minimize the development of objectionable odors and flavors due to rancidity and to prevent or reduce the formation of decomposed products that could be toxic. The development of rancidity also involves the degradation of vitamins, essential fatty acids, and essential amino acids which brings a loss of nutritional value (Nanditha \& Prabhasankar, 2009). This stimulated the alternative use of aromatic plant extracts and EOs as natural antioxidants to protect food products from rancidity (European Food Safety Authority, 2010; Falowo et al., 2014; Fernandes et al., 2016). As an example; extracts of pine bark (Pinus maritima), oregano, rosemary, green tea, nettle (Urtica dioica), and cinnamon perform the role of antioxidants in meat and poultry (Karre et al., 2013; Shah et al., 2014). In addition, Hygreeva et al. (2014) confirmed synergistic antioxidant action of these extracts in inhibition of lipid oxidation in fermented, cooked, and irradiated meat products. However, since the results of antioxidative activity of EOs were obtained with different methods in the literature and hence the numerical comparison is not possible, some researchers also presented a qualitative comparison with the antioxidative activity of BHT and/or BHA (Amorati et al., 2013). As an example, Martínez-Tomé et al. (2001) found the ability of several natural and synthetic compounds to inhibit lipid peroxidation in decreasing order as rosemary $>$ oregano $>$ propyl gallate $>$ annatto $>$ BHA $>$ sweet paprika $>$ cumin $>$ hot paprika $>$ saffron $>$ BHT. Politeo et al. (2006) showed the antioxidant capacity of EOs of twelve aromatic plants, which was determined by four different methods: (DPPH) radical scavenging method, determination of ferric reducing antioxidant power (FRAP), determination of antioxidant activity with thiobarbituric acid reactive species (TBARS), and automatic determination of the oxidative stability of fat (RANCIMAT), in decreasing order as clove $>$ basil $>$ laurel $>$ coriander $>$ nutmeg $>$ black pepper $>$ everlast $>$ mint $>$ marjoram $>$ cinnamon $>$ sage $>$ fennel.

Oregano EOs was shown to protect extra virgin olive oil from oxidation during storage (Asensio et al., 2012).

\subsection{Anti-quorum sensing (anti-QS) and anti-biofilm activities of aromatic plant derivatives}

Production of degrading enzymes, pigments, and bacteriocins, regulation of bioluminescence (Miller \& Bassler 2001), expression of virulence factors, mechanisms of resistance to stress conditions, sporulation, motility, and formation of biofilm depends on bacterial cell density through a phenomenon of "quorum sensing (QS)", in which cells communicate by synthesizing, detecting and reacting to low molecular weight, diffusible, hormone-like signaling molecules called autoinducers (AI) (Gobbetti et al., 2007; Mizan et al., 2016; Machado et al., 2020). Autoinducers accumulate and activate specific receptors associated with transcription signals for controlling these biochemical processes, which are of major importance in bacterial pathogenesis when a "quorum" (e.g., a certain threshold concentration) is reached (Gobbetti et al., 2007; Olivero et al., 2011; Mukherjee \& Bassler, 2019). This will also trigger the dispersion of the biofilm. Gramnegative bacteria use acylated homoserine lactones (AHLs) as autoinducers, and Gram-positive bacteria use ribosomallygenerated oligopeptide called an autoinducing peptide (AIP or peptide pheromone) to communicate (Miller \& Bassler, 2001).

The capacity to behave collectively as a group, which was once believed to be restricted to multicellular organisms, gives bacteria the ability to migrate to a more suitable environment and to adopt new modes of growth, which protects from detrimental environments (De Kievit \& Iglewski, 2000). Moreover, QS plays an important role not only in the development of the food microbial ecology, but also in the spoilage of meat products, milk and dairy products, and vegetables (Galié et al., 2018). Therefore, the disruption of QS could decisively contribute to control the expression of many harmful and pathogenic strains of bacteria. This fact has allowed the development of various studies on the use of anti-quorum sensing (Anti-QS) natural compounds, which specifically block the AHL regulation, not only for the food industry to create new options for food safety 
but also the treatment of infections caused by pathogenic bacteria (Machado et al., 2020).

QS cell-density-dependent regulation of gene expression is a major component of biofilm physiology since biofilms contain high concentrations of bacterial cells (Machado et al., 2020). Biofilms, which are defined as the surface community of microorganisms characterized by cells that are irreversibly associated with a surface, embedded in a matrix of extracellular polymeric substances (EPS), and display an altered phenotype concerning gene expression, protein production, and growth, can be formed on plastic, metal, glass, cement, wood surfaces within the food industry, and also in food products (Cloete et al., 2009). However, these surfaces cannot be colonized by biofilms unless they have been exposed to organic material from their environment (Allison et al., 2000). In the food industry, foodborne pathogenic bacteria, such as S. enterica spp., L. monocytogenes, pathogenic E. coli, Campylobacter spp., S. aureus, Bacillus cereus, and Pseudomonas aeruginosa cause severe hygienic trouble and serious public health risks by both attaching on several food matrices having water activities above $0.9\left(\mathrm{a}_{\mathrm{w}}>0.9\right)$ and wet food processing surfaces and developing biofilms (Chmielewski \& Frank, 2003; Giaouris et al., 2015; Galié et al., 2018). Moreover, biofilms not only contain mixed populations of bacteria but also fungi, protozoa and if conditions are suitable, they can host even higher organisms in the food chain such as nematodes and larvae (Cloete et al., 2009). From another point of view, biofilm-colonized products can be considered adulterated and might be subject to recall. Moreover, biofilm formation presents a large economic burden to the food industry which can also be associated with a negative effect on a company's profitability.

The action of EOs on biofilms depends on the hydrophobicity, reactivity, the diffusion rate of EOs in the matrix, and the composition and structure of the biofilm (Melo et al., 2019). Regarding microbial inactivation in biofilms, aromatic plant derivatives have been reported to mainly affect the cellular membrane by permeabilization (Nazzaro et al., 2013), which leads to the disruption of vital cellular processes, such as membrane transport, energy production, and metabolic regulatory functions (Grigore-Gurgu et al., 2019). Melo et al. (2019) stated that the EOs of Ocimum gratissimum L. [yielded $1.66 \% \mathrm{w} / \mathrm{w}$, with eugenol as the major component $(74.83 \%)$ ] can break off the formation of biofilm of $S$. aureus and $E$. coli by blocking the quorum-sense system, inhibiting the transcription of flagellar genes or by interfering with bacterial motility. EOs can also increase the oxidative stress in microbial cells which leads to damages of intracellular macromolecules and hence cellular apoptosis (Das et al., 2020). Therefore, they can be used as natural quorum-sensing inhibitors (QSIs) in the food industry (Poli et al., 2018).

Cáceres et al. (2020) showed strong inhibitory effects of the EOs of aromatic plants (Lippia origanoides, T. vulgaris, Lippia alba, Cymbopogon martini, Cymbopogon flexuosus, Rosmarinus officinales, S. officinales, Swinglea glutinosa, Tagetes lucida, Satureja viminea, Cananga odorata, Citrus sinensis, and Elettaria cardamomum) on biofilm formation and violacein (quorum sensing-QS) production in a concentration-dependent manner. As another example, EOs of thyme was shown to inhibit significantly the biofilms formed by S. aureus and E. coli (Szczepanski \& Lipski, 2014) and the biofilm formed by B. cereus (Kang et al., 2018). EOs of Piper bredemeyeri, P. brachypodom, and Piper bogotence found in Colombian flora had 50\% inhibitory concentration ( $\left.\mathrm{IC}_{50}\right)$ for quorum sensing of $45.6 \mu \mathrm{g} / \mathrm{mL}, 93.1 \mu \mathrm{g} / \mathrm{mL}$, and $513.8 \mu \mathrm{g} /$ $\mathrm{mL}$, respectively which increases the use of them in possible control of bacterial diseases (Olivero et al., 2011). EOs of sage, lemon, juniper, and marjoram have been examined in the food industry and reported as effective QSIs against B. cereus, E. coli, and Pichia anomala (Kerekes et al., 2015; Luciardi et al., 2016). EOs of S. aromaticum (clove) and Mentha spicata (spearmint) inhibited the biofilm of Listeria spp., while in the presence of their main compounds alone, namely eugenol and R-(-) carvone, respectively, the biofilm biomass was increased (Chauhan et al., 2009; Leonard et al., 2010). In addition, Camele et al. (2019) reported an overview of the principal constituents of some EOs extracted from different aromatic plants which display anti-QS activity. Among them, members of the family Lamiaceae have promising anti-QS properties to combat different food pathogenic microorganisms.

\section{The use of aromatic plant derivatives in active packaging (AP) systems}

There has been a rising demand for fresh, healthy, and safe food products which are in packaging materials especially obtained from renewable and biodegradable sources (RibeiroSantos et al., 2017). This led researchers to investigate new advances in packaging systems, leading to the development of several packaging technologies including passive, active, smart, and intelligent packages (Salgado et al., 2019). Among them, active packaging (AP) systems have also functioned beyond the containment and protection of the product (Amorati et al., 2013).

AP systems are innovative packaging technology in which the foods, the packaging material, and the environment interact to prolong the shelf-life of food products by inactivation or degradation of undesirable compounds, and to enhance the sensory properties while maintaining the quality of the foods by creating a barrier to the outside environment (Suppakul et al., 2003; Sharma et al., 2021). AP systems employ antimicrobials or oxygen scavenging antioxidants or include moisture absorption and control, and carbon dioxide and ethanol generation systems to protect foods from contamination or degradation or include emitters of flavor, aroma, and other compounds (Khezerlou \& Jafari, 2020). According to the Regulation 1935/2004/EC and the Regulation 450/2009/EC, active materials which are slowly released into the food product in the active packing are referred to as "materials and articles that are intended to extend the shelflife or to maintain or improve the condition of packaged food" (Carpena et al., 2021). Among these molecules, polyphenols, flavonoids, tocopherols, pigments or particularly EOs of aromatic plants are considered target compounds to be included in AP systems due to their volatile aroma compounds. In addition, they also have antimicrobial and antioxidant properties which can enhance the shelf-life of the food products (Atarés \& Chiralt, 2016; Carpena et al., 2021). Since the incorporation of particular materials into AP systems may also affect the safety of food products, the use of EOs in active packaging can also 
reduce food safety risks both raised from synthetic additives (Sharma et al., 2021) and absorbent pads in food packaging. Besides, it is a cost-saving alternative that has the potential to eliminate food safety risks (Domínguez et al., 2018).

As an example, EOs of aromatic plants can preferably be added into the absorbent pads to overcome the unsanitary juices trapped in pads during the shelf-life of foods which causes undesirable odors, spoilage, and potential growth of foodborne pathogens (Martillanes et al., 2017). Overall, this packaging system has an advantage in the reduction of foodborne illness outbreaks and food recalls (Vilela et al., 2018).

The application of EOs in AP can be used in the forms of films and coatings (Sharma et al., 2021). The EOs can be in a separate container or be directly incorporated into the packaging material in which they can be released during transportation and storage of food and contributing to prolonging food shelf-life (Wen et al., 2016; Ribeiro-Santos et al., 2017). Packaging and coating incorporated with EOs increase surface hydrophobicity and the UV barrier property (Sharma et al., 2021). EOs incorporated into films and coatings have been applied in meat, dairy, fish, and bakery products, resulting in prolonged shelf-life and enhanced quality (Ribeiro-Santos et al., 2017; Domínguez et al., 2018).

The antioxidative capacity of EOs incorporated films depends on the intrinsic activity of EOs and film permeability to oxygen (Atarés \& Chiralt, 2016). On the other hand, side-effects of incorporation of EOs into the polymer network may arise due to the induction of undesirable microstructural changes in the properties of films and coatings. This can be overcome by encapsulation of EOs in packaging materials (RibeiroSantos et al., 2017).

Examples of AP incorporating a large variety of EOs from different aromatic plants such as basil, chamomile (Matricaria chamomilla L.), cardamom (Elettaria cardamomum (L.) Maton), and rosemary were compiled by Ribeiro-Santos et al. (2017). Lin et al. (2018) also showed that AP containing thyme essential oil/ $\beta$-cyclodextrin $\varepsilon$-polylysine nanoparticles (TCPNs) improves the antimicrobial properties against Campylobacter jejuni in chicken soup since transmission electron microscopy (TEM) and SDS-PAGE results confirmed the damaged cell membrane and proteins leakage. A mixture of EOs of cinnamon and clove was found to inhibit the growth of spoilage bacteria, yeasts, and fungi usually found on intermediate moisture foods, and thus seems to be a good alternative to synthetic preservatives used in AP systems (Calo et al., 2015). An AP system for chicken meat that, incorporating EOs of rosemary at $4 \%(\mathrm{w} / \mathrm{w})$, inhibits the increase of biogenic amines (putrescine, histamine, and cadaverine) as well as Pseudomonas spp., Brochothrix thermosphacta involved in their production (Sirocchi et al., 2013). Suppakul et al. (2008) used low-density polyethylene (LDPE)-based films containing linalool or methyl chavicol in wrapping Cheddar cheeses which were contaminated with E. coli or L. innocua, stored them at refrigerated $\left(4^{\circ} \mathrm{C}\right)$ or abuse $\left(12^{\circ} \mathrm{C}\right)$ temperatures. After 15 days, they found that methyl chavicol-LDPE-based film exhibited a higher efficacy of inhibition than that of linalool-LDPE-based film. Fernández-Pan et al. (2014) found that whey protein-based film containing EOs of oregano or clove can protect chicken breast fillets against food spoilage microorganisms, such as aerobic mesophilic and psychrotrophic bacteria, Pseudomonas spp. and lactic acid bacteria. Ait-Ouazzou et al. (2011) used polyvinyl alcohol nanofibrous films containing EOs of cinnamon for masking its intense flavor while providing antibacterial activity against Gram-positive and Gram-negative bacteria.

\section{Benefits of vegetal bioactive compounds in health and disease}

Traditional plant foods constitute the main source of functional ingredients with beneficial effects to the nutrition and human health (Charalampopoulos et al., 2002; Hasler, 2002; Hamed et al., 2015).

The World Health Organization states that $80 \%$ of the total world population use traditional food and practices having trust to their beneficial impact for health (Bodeker et al., 2005). Due to their natural provenance, consumers believe that the plantbased products are safe. In this vein, food companies focused their interest on the rapid deployment of plant-based fortified products with high nutritional value and functional bioactive ingredients to reduce the occurrence of chronic diseases which are the functional foods (Prakash et al., 2017).

Another issue is that enormous quantities of foods are spoiled each year due to either microbial spoilage or chemical deterioration (Prakash et al., 2017). Likewise, functional foods are perishable to both chemical and microbial decaying. Thus, researchers center their interest on the development of natural products in foods to preserve the food quality and extend its shelf-life as previously discussed.

Research showed that aromatic and herbal plants are bestowed with functional ingredients that may have an immunoregulatory potential (Wadood et al., 2013; Sharma et al., 2017) and protect human body against pathogenic invaders. They could be used as an adjunctive treatment boosting the immune system, enhancing the mucosal barrier function, and inhibit bacterial adherence and invasion capacity in the intestinal epithelium by being in direct antagonism with pathogens (Bezirtzoglou $\&$ Stavropoulou, 2011).

Nutraceuticals are medicinal foods from herbal or botanical raw materials that boost health, regulate immunity, and thereby prevent or treat different types of acute or chronic diseases. In this line, important antimicrobial activities of EOs produced from aromatic plants were revealed with potential interest for prophylaxis or therapy (Fournomiti et al., 2015). The effect of EOs produced from aromatic plants was shown on the seizure latency and severity of pentylenetetrazol- (PTZ-) induced seizures in mice. Yet, mice administered Mentha piperita had shown no seizures and survival (Koutroumanidou et al., 2013). Research showed that the main potent component of Mentha is an essential oil, although high polymorphism and variation in components is observed among the different EOs from Mentha (Chauhan et al., 2009).

Modulation of inflammation status was succeeded utilizing medicinal plants as an alternate or adjuvant therapy. Due to their potential impact as scavengers of free radicals, there is evidence that EOs slip successfully into the prevention of brain dysfunction, cancer, heart disease, and immune system disturbances that may result from cellular damage (Aruoma, 1998). It is also of note 
that bacterial phagocytosis occurring during inflammation is highly increasing the oxygen consumption (superoxide anion radical (O2-) swiftly converted to hydrogen peroxide (H2O2) (Aruoma, 1998; Miguel, 2010).

Traditionally multiple medicinal plants and herbs have been used for relieving symptoms of gastrointestinal diseases from dyspepsia to irritable bowel syndrome (IBS) and chronic inflammatory bowel diseases (IBD). (Schilcher et al., 2016; Kelber et al., 2017).

Gut microbiota plays a key role in the development of gastrointestinal diseases. Bacterial overgrowth, gut dysbiosis and imbalance of the gut microbiota is observed in the small intestine in IBS patients (Barbara et al., 2016) and patients with Chronic inflammatory bowel diseases (IBD) such as Crohn's disease and ulcerative colitis (Bürger et al., 2015).

Medicinal plants and herbs are shown to possess beneficial effects such as hypoglycemic properties and optimization of markers related to the disease (Al-Snafi et al., 2019). In this vein, research was launched all over the world to understand the therapeutic impact and the potential antidiabetic activities of medicinal aromatic plants (Clark et al., 1998; Ganesan et al., 2012; Enwa et al., 2013; Enwa, 2014; Dong et al., 2012; Hajimonfarednejad et al., 2018; Bezirtzoglou et al., 2021) by isolation of drastic compounds, biological testing of plants extracts, pharmacodynamics, toxicity test and finally clinical studies.

Inflammation, insulin resistance, and metabolic disorders coexist in obesity (World Health Organization, 2020). Medicinal plants alone or in association showed the same beneficial effects for the treatment of obesity.

\section{Concluding remarks}

Consumer awareness about natural food products has increased drastically and this has fueled the investigation for natural food additives in recent years. Therefore, the use of aromatic plant derivatives in food production can fill this gap with many benefits from an integrated food application point in sustainable human health. Food producers are also interested in using low-processed and/or functional foods by opting for "clear labels" according to consumer requirements. This is a challenge and a great opportunity for the food industry to incorporate aromatic plant derivatives in their product formulations to replace or supplement synthetic additives while maintaining product quality. Therefore, the food industry uses the extracts and EOs of aromatic plants either as flavoring agents, natural antioxidants, or preservatives to improve the quality, to maintain the long-term stability, and to extend the shelf-life of food products by preventing oxidation and activities of saprophytic microorganisms, and to increase food safety by controlling the foodborne pathogens. As the EOs of aromatic plants are composed of phenolic compounds, with antimicrobial and antioxidant activity that minimize or eliminate microbial growth and/or reduce the effect of lipid oxidation, they are also used in AP systems, which is a flourishing field due to the care towards natural-based additives. However, market studies need to be done before the commercialization of EOs incorporated new AP materials to know the acceptance of consumers to these new products. In addition, it should not be forgotten that the effectiveness of the application of these compounds in food production varies depending on the form of application, their concentration, the way they are applied, and finally the storage temperature and conditions. Since the QS mechanism regulates the formation of bacterial biofilms, destroying and/ or disrupting can help prevent the formation of biofilms and subsequently solve many health issues. In addition, since biofilm formation can lead to losses due to equipment corrosion, duct blockage, reduced heat transfer, food spoilage, and loss of time and money for the food industry, aromatic plant derivates are good alternatives to other strategies in control biofilm formation or removal when these formations need to be removed. Their use in the food industry will help to eradicate undesirable and pathogenic microorganisms from food processing environments and, subsequently, from food products.

Consumer demands for minimal processing foods and foods containing naturally derived preservatives, with potential health benefits, likely support the sharp increase in the food applications of aromatic plant derivatives in the future. The direct use of aromatic plant derivatives is not rational nowadays due to the lack of a full understanding of their mechanism of action and eventual interactions with food and other components. However, future research into the use of aromatic plant derivatives in combination with other technologies in a multi-barrier conservation approach will enhance the efficiency of their use as natural antimicrobials, especially in the production of novel food products with improved shelf-life and enhanced nutritional properties. In this respect, it is possible to contribute to the UN 2030 Agenda and Sustainable Development Goals (SDGs) by using natural plant resources, especially in the production of new foods with human health-promoting properties, and thus in improving nutrition. In this way, the healthy and safe food needs of present and future generations can be supported and hence good health and well-being can be provided. Besides, aromatic plants contain much more valuable ingredients that have not yet been tested in food applications for their antimicrobial properties, as they need regulatory approval before they can be used as a food preservative. Furthermore, aromatic plant derivatives that show target sites other than those used with antibiotics may be shown to have inhibitory effects against drugresistant foodborne pathogens in future studies. Finally, more studies need to be developed on the synergy and competition of EO components to strengthen our knowledge in this area by achieving collaborative research with structured methodology, concepts, and ethics for aromatic research.

\section{Conflict of interest}

The authors declare that the research was conducted in the absence of any commercial or financial relationships that could be construed as a potential conflict of interest.

\section{Author contributions}

B.M T., E.S., L.K.W., and E.B.; drafting, revising, and approving the final paper. All authors have read and agreed to the published version of the manuscript.

\section{Acknowledgements}

This research received no external funding. 


\section{References}

Ait-Ouazzou, A., Cherrat, L., Espina, L., Lorán, S., Rota, C., \& Pagán, R. (2011). The antimicrobial activity of hydrophobic essential oil constituents acting alone or in combined processes of food preservation. Innovative Food Science \& Emerging Technologies, 12(3), 320-329. http://dx.doi.org/10.1016/j.ifset.2011.04.004.

Alenisan, M. A., Alqattan, H. H., Tolbah, L. S., \& Shori, A. B. (2017). Antioxidant properties of dairy products fortified with natural additives: a review. Journal of Association of Arab Universities for Basic and Applied Sciences, 24(1), 101-106. http://dx.doi.org/10.1016/j. jaubas.2017.05.001.

Alizadeh, A. M., Amirhossein Golzan, S., Mahdavi, A., Dakhili, S., Torki, Z., \& Hosseini, H. (2021). Recent advances on the efficacy of essential oils on mycotoxin secretion and their mode of action. Critical Reviews in Food Science and Nutrition. In press. http://dx.doi. org/10.1080/10408398.2021.1878102. PMid:33523705.

Allison, D. G., Gilbert, P., Lappin-Scott, H. M., \& Wilson, M. (2000). Community structure and co-operation in biofilms. Cambridge: University Press. http://dx.doi.org/10.1017/CBO9780511754814.

Al-Snafi, A. E., Majid, W. J., Talab, T. A., \& Al-Battat, A. A. (2019). Medicinal plants with antidiabetic effects-an overview (Part 1). IOSR Journal of Pharmacy, 9(3I), 9-46.

Al-Sum, B. A., \& Al-Arfaj, A. A. (2013). Antimicrobial activity against extract of mint plant. Science Journal of Clinical Medicine, 2(3), 110113. http://dx.doi.org/10.11648/j.sjcm.20130203.19.

American Botanical Council - ABC. (2019). Terminology. Austin. Retrieved from http://abc.herbalgram.org/site/PageServer?pagename=Terminology

Amorati, R., Foti, M. C., \& Valgimigli, L. (2013). Antioxidant activity of essential oils. Journal of Agricultural and Food Chemistry, 61(46), 10835-10847. http://dx.doi.org/10.1021/jf403496k. PMid:24156356.

Antolak, H., \& Kregiel, D. (2017). Food preservatives from plants. In D. N. Karunaratne \& G. Pamunuwa (Eds.), Food additives. London: IntechOpen. Retrieved from https://www.intechopen.com/books/ food-additives/food-preservatives-from-plants

Arranz, E., Mes, J., Wichers, H. J., Jaime, L., Mendiola, J. A., Reglero, G., \& Santoyo, S. (2015). Anti-inflammatory activity of the basolateral fraction of Caco-2 cells exposed to a rosemary supercritical extract. Journal of Functional Foods, 13, 384-390. http://dx.doi.org/10.1016/j. jff.2015.01.015.

Aruoma, O. I. (1998). Free radicals, oxidative stress, and antioxidants in human health and disease. Journal of the American Oil Chemists' Society, 75(2), 199-212. http://dx.doi.org/10.1007/s11746-998-00329. PMid:32287334.

Asensio, C. M., Nepote, V., \& Grosso, N. R. (2012). Sensory attribute preservation in extra virgin olive oil with addition of oregano essential oil as natural antioxidant. Journal of Food Science, 77(9), S294-S301. http://dx.doi.org/10.1111/j.1750-3841.2012.02841.x. PMid:22897359.

Atarés, L., \& Chiralt, A. (2016). Essential oils as additives in biodegradable films and coatings for active food packaging. Trends in Food Science \& Technology, 48, 51-62. http://dx.doi.org/10.1016/j.tifs.2015.12.001.

Bajpai, V. K., Baek, K.-H., \& Kang, S. C. (2012). Control of Salmonella in foods by using essential oils: a review. Food Research International, 45(2), 722-734. http://dx.doi.org/10.1016/j.foodres.2011.04.052.

Bakkali, F., Averbeck, S., Averbeck, D., \& Idaomar, M. (2008). Biological effects of essential oils: a review. Food and Chemical Toxicology, 46(2), 446-475. http://dx.doi.org/10.1016/j.fct.2007.09.106. PMid:17996351.

Barbara, G., Feinle-Bisset, C., Ghoshal, U. C., Santos, J., Vanner, S. J., Vergnolle, N., Zoetendal, E. G., \& Quigley, E. M. (2016). The intestinal microenvironment and functional gastrointestinal disorders. Gastroenterology, 150(6), 1305-1318.e8. http://dx.doi.org/10.1053/j. gastro.2016.02.028. PMid:27144620.

Bassolé, I., \& Juliani, H. (2012). Essential oils in combination and their antimicrobial properties. Molecules, 17(4), 3989-4006. http://dx.doi. org/10.3390/molecules17043989. PMid:22469594.

Bento, M. H. L., Ouwehand, A. C., Tiihonen, K., Lahtinen, S., Nurminen, P., Saarinen, M., Schulze, H., Mygind, T., \& Fischer, J. (2013). Essential oils and their use in animal feeds for monogastric animals-effects on feed quality, gut microbiota, growth performance and food safety: a review. Veterinary Medicine, 58(9), 449-458. http://dx.doi. org/10.17221/7029-VETMED.

Bernardes, W. A., Lucarini, R., Tozatti, M. G., Souza, M. G., Silva, M. L., Silva, A. A., Fo., Martins, C. H., Crotti, A. E., Pauletti, P. M., Groppo, M., \& Cunha, W. R. (2010). Antimicrobial activity of Rosmarinus officinalis against oral pathogens: relevance of carnosic acid and carnosol. Chemistry \& Biodiversity, 7(7), 1835-1840. http://dx.doi. org/10.1002/cbdv.200900301. PMid:20658673.

Bezirtzoglou, E., \& Stavropoulou, E. (2011). Immunology and probiotic impact of the newborn and young children intestinal microflora. Anaerobe, 17(6), 369-374. http://dx.doi.org/10.1016/j. anaerobe.2011.03.010. PMid:21515397.

Bezirtzoglou, E., Stavropoulou, E., Kantartzi, K., Tsigalou, C., Voidarou, C., Mitropoulou, G., Prapa, I., Santarmaki, V., Kompoura, V., Yanni, A. E., Antoniadou, M., Varzakas, T., \& Kourkoutas, Y. (2021). Maintaining digestive health in diabetes: the role of the gut microbiome and the challenge of functional foods. Microorganisms, 9(3), 516. http://dx.doi.org/10.3390/microorganisms9030516. PMid:33802371.

Bhavaniramya, S., Vishnupriya, S., Al-Aboody, M. S., Vijayakumar, R., \& Baskaran, D. (2019). Role of essential oils in food safety: Antimicrobial and antioxidant applications. Grain \& Oil Science and Technology, 2(2), 49-55. http://dx.doi.org/10.1016/j.gaost.2019.03.001.

Bodeker, G., Ong, C.-K., Grundy, C., Burford, G., \& Shein, K. (2005). WHO global atlas of traditional, complementary and alternative medicine. Geneva: World Health Organization.

Borugă, O., Jianu, C., Mişcă, C., Goleț, I., Gruia, A. T., \& Horhat, F. G. (2014). Thymus vulgaris essential oil: chemical composition and antimicrobial activity. Journal of Medicine and Life, 7(3), 56-60. PMid:25870697.

Boukhatem, M. N., \& Setzer, W. N. (2020). Aromatic herbs, medicinal plant-derived essential oils, and phytochemical extracts as potential therapies for Coronaviruses: future perspectives. Plants, 9(6), 800. http://dx.doi.org/10.3390/plants9060800. PMid:32604842.

Bozin, B., Mimica-Dukic, N., Samojlik, I., \& Jovin, E. (2007). Antimicrobial and antioxidant properties of rosemary and sage (Rosmarinus officinalis L. and Salvia officinalis L., Lamiaceae) essential oils. Journal of Agricultural and Food Chemistry, 55(19), 7879-7885. http://dx.doi.org/10.1021/jf0715323. PMid:17708648.

Bruni, R., Medici, A., Andreotti, E., Fantin, C., Muzzoli, M., Dehesa, M., Romagnoli, C., \& Sacchetti, G. (2004). Chemical composition and biological activities of Ishpingo essential oil, a traditional Ecuadorian spice from Ocotea quixos (Lam.) Kosterm. (Lauraceae) flower calices. Food Chemistry, 85(3), 415-421. http://dx.doi.org/10.1016/j. foodchem.2003.07.019.

Bürger, M., Lange, K., \& Stallmach, L. A. (2015). Intestinales mikrobiom und chronisch-entzündliche darmerkrankungen: feindschaft oder freundschaft? Gastroenterology, 10(2), 87-101. http://dx.doi. org/10.1007/s11377-014-0963-7.

Buriani, A., Fortinguerra, S., Sorrenti, V., Caudullo, G., \& Carrara, M. (2020). Essential oil phytocomplex activity, a review with a focus on multivariate analysis for a network pharmacology-informed 
phytogenomic approach. Molecules, 25(8), 1833. http://dx.doi. org/10.3390/molecules25081833. PMid:32316274.

Burt, S. (2004). Essential oils: their antibacterial properties and potential applications in foods - a review. International Journal of Food Microbiology, 94(3), 223-253. http://dx.doi.org/10.1016/j. ijfoodmicro.2004.03.022. PMid:15246235.

Cáceres, M., Hidalgo, W., Stashenko, E., Torres, R., \& Ortiz, C. (2020). Essential oils of aromatic plants with antibacterial, anti-biofilm and anti-quorum sensing activities against pathogenic bacteria. Antibiotics, 9(4), 147. http://dx.doi.org/10.3390/antibiotics9040147. PMid:32235590.

Calo, J. R., Crandall, P. G., O’Bryan, C. A., \& Ricke, S. C. (2015). Essential oils as antimicrobials in food systems - a review. Food Control, 54, 111-119. http://dx.doi.org/10.1016/j.foodcont.2014.12.040.

Camele, I., Elshafie, H. S., Caputo, L., \& De Feo, V. (2019). Anti-quorum sensing and antimicrobial effect of Mediterranean plant essential oils against phytopathogenic bacteria. Frontiers in Microbiology, 10, 2619. http://dx.doi.org/10.3389/fmicb.2019.02619. PMid:31803159.

Campos, T., Barreto, V., Queiros, R., Ricardo-Rodrigues, S., Felix, M. R., \& Laranjo, M. (2016). Use of essential oils in food preservation, Conservacao de morangos com utilizacao de oleosessenciais. Agrotech Journal, 18, 90-96.

Carpena, M., Nuñez-Estevez, B., Soria-Lopez, A., Garcia-Oliveira, P., \& Prieto, M. A. (2021). Essential oils and their application on active packaging systems: a review. Resources, 10(1), 7. http://dx.doi. org/10.3390/resources10010007.

Charalampopoulos, D., Wang, R., Pandiella, S. S., \& Webb, C. (2002). Application of cereals and cereal components in functional foods: a review. International Journal of Food Microbiology, 79(1-2), 131. http://dx.doi.org/10.1016/S0168-1605(02)00187-3. PMid:12382693.

Chauhan, R. S., Kaul, M. K., Shahi, A. K., Kumar, A., Ram, G., \& Tawa, A. (2009). Chemical composition of essential oils in Mentha spicata L. accession [IIIM(J)26] from North-West Himalayan region, India. Industrial Crops and Products, 29(2-3), 654-656. http://dx.doi. org/10.1016/j.indcrop.2008.12.003.

Chaves, T. P., Pinheiro, R. E. E., Melo, E. S., Soares, M. J. S., Souza, J. S. N., Andrade, T. B., Lemos, T. L. G., \& Coutinho, H. D. M. (2018). Essential oil of Eucalyptus camaldulensis Dehn potentiates $\beta$-lactam activity against Staphylococcus aureus and Escherichia coli resistant strains. Industrial Crops and Products, 112, 70-74. http://dx.doi. org/10.1016/j.indcrop.2017.10.048.

Cherrat, L., Espina, L., Bakkali, M., García-Gonzalo, D., Pagán, R., \& Laglaoui, A. (2014). Chemical composition and antioxidant properties of Laurus nobilis L. and Myrtus communis L. essential oils from Morocco and evaluation of their antimicrobial activity acting alone or in combined processes for food preservation. Journal of the Science of Food and Agriculture, 94(6), 1197-1204. http://dx.doi. org/10.1002/jsfa.6397. PMid:24105704.

Chmielewski, R. A. N., \& Frank, J. F. (2003). Biofilm formation and control in food processing facilities. Comprehensive Reviews in Food Science and Food Safety, 2(1), 22-32. http://dx.doi.org/10.1111/j.1541-4337.2003. tb00012.x. PMid:33451238.

Christaki, E., Bonos, E., Giannenas, I., \& Florou-Paneri, P. (2012). Aromatic plants as a source of bioactive compounds. Agriculture, 2(4), 228-243. http://dx.doi.org/10.3390/agriculture2030228.

Clark, K. J., Grant, P. G., Sarr, A. B., Belakere, J. R., Swaggerty, C. L., Phillips, T. D., \& Woode, G. N. (1998). An in vitro study of theaflavins extracted from black tea to neutralize bovine rotavirus and bovine coronavirus infections. Veterinary Microbiology, 63(2-4), 147-157. http://dx.doi.org/10.1016/S0378-1135(98)00242-9. PMid:9850995.
Cloete, E., Molobela, I., Van Der Merwe, A., \& Richards, M. (2009). Biofilms in the food and beverage industries: an introduction. In P. M. Fratamico, B. A. Annous \& N. W. Gunther (Eds.), Biofilms in the food and beverage industries (pp. 3-41). Cambridge: Woodhead Publishing. http://dx.doi.org/10.1533/9781845697167.1.3.

Das, S., Vörös-Horváth, B., Bencsik, T., Micalizzi, G., Mondello, L., Horváth, G., Kőszegi, T., \& Széchenyi, A. (2020). Antimicrobial activity of different Artemisia essential oil formulations. Molecules, 25(10), 2390. http://dx.doi.org/10.3390/molecules25102390. PMid:32455592.

Dauqan, E. M., \& Abdullah, A. (2017). Medicinal and functional values of thyme (Thymus vulgaris L.) herb. Journal of Applied Biochemistry and Biotechnology, 5(2), 17-22. http://dx.doi.org/10.7324/JABB.2017.50203.

De Kievit, T. R., \& Iglewski, B. H. (2000). Bacterial quorum sensing in pathogenic relationships. Infection and Immunity, 68(9), 4839-4849. http://dx.doi.org/10.1128/IAI.68.9.4839-4849.2000. PMid:10948095.

Demir, A., Mercanoglu Taban, B., Arslan, M., Yesilada, E., \& Aytac, S. A. (2009). Antimicrobial Effect of Helichrysum plicatum subsp. plicatum. Pharmaceutical Biology, 47(4), 289-297. http://dx.doi. org/10.1080/13880200802590434.

Demo, M., Oliva, M. M., López, M. L., Zunino, M. P., \& Zygadlo, J. A. (2005). Antimicrobial activity of essential oils obtained from aromatic plants of Argentina. Pharmaceutical Biology, 43(2), 129-134. http:// dx.doi.org/10.1080/13880200590919438.

Domínguez, R., Barba, F. J., Gómez, B., Putnik, P., Bursać Kovačević, D., Pateiro, M., Santos, E. M., \& Lorenzo, J. M. (2018). Active packaging films with natural antioxidants to be used in meat industry: a review. Food Research International, 113, 93-101. http://dx.doi.org/10.1016/j. foodres.2018.06.073. PMid:30195551.

Dong, H., Wang, N., Zhao, L., \& Lu, F. (2012). Berberine in the treatment of type 2 diabetes mellitus: a systemic review and meta-analysis. Evidence-Based Complementary and Alternative Medicine, 2012, 591654. http://dx.doi.org/10.1155/2012/591654. PMid:23118793.

Dziki, D., Rózyło, R., Gawlik-Dziki, U., \& Swieca, M. (2014). Current trends in the enhancement of antioxidant activity of wheat bread by the addition of plant materials rich in phenolic compounds. Trends in Food Science \& Technology, 40(1), 48-61. http://dx.doi. org/10.1016/j.tifs.2014.07.010.

Ebadollahi, A. (2013). Essential oils isolated from myrtaceae family as natural insecticides. Annual Research \& Review in Biology, 3(3), 148-175.

El-Nekeety, A. A., Mohamed, S. R., Hathout, A. S., Hassan, N. S., Aly, S. E., \& Abdel-Wahhab, M. A. (2011). Antioxidant properties of Thymus vulgaris oil against aflatoxin-induce oxidative stress in male rats. Toxicon, 57(7-8), 984-991. http://dx.doi.org/10.1016/j. toxicon.2011.03.021. PMid:21477612.

Elshafie, H. Z., \& Camele, I. (2017). An overview of the biological effects of some Mediterranean essential oils on human health. BioMed Research International, 2017, 9268468. http://dx.doi. org/10.1155/2017/9268468. PMid:29230418.

Enwa, F. O. (2014). Mechanisms of antimicrobial actions of phytochemicals against enteric pathogens-a review. Research Journal of Pharmaceutical, Biological and Chemical Sciences, 2(2), 77-85.

Enwa, F. O., Omojate, C. G., \& Adonu, C. A. (2013). review on the phytochemical profile and the antibacterial susceptibility pattern of some clinical isolates to the ethanolic leaves extract of Moringaoleifera lam (moringaceae). International Journal of Advanced Research, 1(5), 226-238.

Erkan, N., Ayranci, G., \& Ayranci, E. (2008). Antioxidant activities of rosemary (Rosmarinus officinalis L.) extract, blackseed (Nigella sativa $\mathrm{L}$.) essential oil, carnosic acid, rosmarinic acid and sesamol. 
Food Chemistry, 110(1), 76-82. http://dx.doi.org/10.1016/j. foodchem.2008.01.058. PMid:26050168.

European Food Safety Authority - EFSA. (2010). Panel on food additives and nutrient sources added to food (ANS). Scientific opinion on the reevaluation of butylated hydroxytoluene BHT (E 321) as a food additive. EFSA Journal, 10, 2588-2630.

Fachini-Queiroz, F. C., Kummer, R., Estevão-Silva, C. F., Carvalho, M. D. D. B., Cunha, J. M., Grespan, R., Bersani-Amado, C. A., \& Cuman, R. K. N. (2012). Effects of thymol and carvacrol, constituents of Thymus vulgaris L. essential oil, on the inflammatory response. Evidence-Based Complementary and Alternative Medicine, 2012, 657026. http://dx.doi.org/10.1155/2012/657026. PMid:22919415.

Faleiro, M. L. (2011). The mode of antibacterial action of essential oils. In A. Méndez-Vilas (Ed). Science against microbial pathogens: communicating current research and technological advances (pp. 1143-1156). Badajoz: Formatex Research Center.

Falowo, A. B., Fayemi, P. O., \& Muchenje, P. O. (2014). Natural antioxidants against lipid-protein oxidative deterioration in meat and meat products: a review. Food Research International, 64, 171-181. http://dx.doi.org/10.1016/j.foodres.2014.06.022. PMid:30011637.

Fernandes, R. P. P., Trindade, M. A., Tonin, F. G., Lima, C. G., Pugine, S. M. P., Munekata, P. E. S., Lorenzo, J. M., \& Melo, M. P. (2016). Evaluation of antioxidant capacity of 13 plant extracts by threedifferent methods: cluster analyses applied for selectionof the natural extracts with higher antioxidant capacity to replace synthetic antioxidant in lamb burgers. Journal of Food Science and Technology, 53(1), 451460. http://dx.doi.org/10.1007/s13197-015-1994-x. PMid:26787964.

Fernández-López, J., \& Viuda-Martos, M. (2018). Introduction to the special issue: application of essential oils in food systems. Foods, 7(4), 56. http://dx.doi.org/10.3390/foods7040056. PMid:29621143.

Fernández-Pan, I., Carrión-Granda, X., \& Maté, J. I. (2014). Antimicrobial efficiency of edible coatings on the preservation of chicken breast fillets. Food Control, 36(1), 69-75. http://dx.doi.org/10.1016/j. foodcont.2013.07.032.

Filipčev, B. (2020). The effects of aromatic plants and their extracts in food products. In P Florou-Paneri, E Christaki, \& I Giannenas (Eds.), Feed additives (pp. 279-294). London: Academic Press. http:// dx.doi.org/10.1016/B978-0-12-814700-9.00016-9.

Fisher, K., \& Phillips, C. A. (2008). Potential antimicrobial uses of essential oils in food: is citrus the answer. Trends in Food Science \& Technology, 19(3), 156-164. http://dx.doi.org/10.1016/j.tifs.2007.11.006.

Fournomiti, M., Kimbaris, A., Mantzourani, I., Plessas, S., Theodoridou, I., Papaemmanouil, V., Kapsiotis, I., Panopoulou, M., Stavropoulou, E., Bezirtzoglou, E., \& Alexopoulos, A. (2015). Antimicrobial activity of essential oils of cultivated oregano (Origanum vulgare), sage (Salvia officinalis), and thyme (Thymus vulgaris) against clinical isolates of Escherichia coli, Klebsiella oxytoca, and Klebsiella pneumoniae. Microbial Ecology in Health and Disease, 26(0), 23289. http://dx.doi. org/10.3402/mehd.v26.23289. PMid:25881620.

Galié, S., García-Gutiérrez, C., Miguélez, E. M., Villar, C. J., \& Lombó, F. (2018). Biofilms in the food industry: health aspects and control methods. Frontiers in Microbiology, 9, 898. http://dx.doi.org/10.3389/ fmicb.2018.00898. PMid:29867809.

Ganesan, S., Faris, A. N., Comstock, A. T., Wang, Q., Nanua, S., Hershenson, M. B., \& Sajjan, U. S. (2012). Quercetin inhibits rhinovirus replication in vitro and in vivo. Antiviral Research, 94(3), 258-271. http://dx.doi.org/10.1016/j.antiviral.2012.03.005. PMid:22465313.

Gaucher, M.-L., Quessy, S., Letellier, A., Arsenault, J., \& Boulianne, M. (2015). Impact of a drug-free program on broiler chicken growth performances, gut health, Clostridium perfringens and Campylobacter jejuni occurrences at the farm level. Poultry Science, 94(8), 1791-1801. http://dx.doi.org/10.3382/ps/pev142. PMid:26047674.

Giacometti, J., Bursać Kovačević, D., Putnik, P., Gabrić, D., Bilušić, T., Krešić, G., Stulić, V., Barba, F. J., Chemat, F., Barbosa-Cánovas, G., \& Režek Jambrak, A. (2018). Extraction of bioactive compounds and essential oils from Mediterranean herbs by conventional and green innovative techniques: a review. Food Research International, 113, 245-262. http://dx.doi.org/10.1016/j.foodres.2018.06.036. PMid:30195519.

Giannenas, I., Bonos, E., Christaki, E., \& Florou-Paneri, P. (2013). Essential oils and their applications in animal nutrition. Medicinal \& Aromatic Plants, 2(6), 1000140. http://dx.doi.org/10.4172/21670412.1000140 .

Giannenas, I., Sidiropoulou, E., Bonos, E., Christaki, E., \& Florou-Paneri, P. (2020). The history of herbs, medicinal and aromatic plants, and their extracts: Past, current situation and future perspectives. In $\mathrm{P}$ Florou-Paneri, E Christaki, \& I Giannenas (Eds.), Feed additives (pp. 1-18). London: Academic Press. http://dx.doi.org/10.1016/ B978-0-12-814700-9.00001-7.

Giaouris, E., Heir, E., Desvaux, M., Hébraud, M., Møretrø, T., Langsrud, S., Doulgeraki, A., Nychas, G.-J., Kačániová, M., Czaczyk, K., Ölmez, H., \& Simões, M. (2015). Intra- and inter-species interactions within biofilms of important foodborne bacterial pathogens. Frontiers in Microbiology, 6, 841. http://dx.doi.org/10.3389/fmicb.2015.00841. PMid:26347727.

Gibriel, A. Y., Al-Sayed, H. M. A., Rady, A. H., \& Abdelaleem, M. A. (2013). Synergistic antibacterial activity of irradiated and nonirradiated cumin, thyme and rosemary essential oils. Journal of Food Safety, 33(2), 222-228. http://dx.doi.org/10.1111/jfs.12043.

Gobbetti, M., De Angelis, M., Di Cagno, R., Minervini, F., \& Limitone, A. (2007). Cell-cell communication in food related bacteria. International Journal of Food Microbiology, 120(1-2), 34-45. http:// dx.doi.org/10.1016/j.ijfoodmicro.2007.06.012. PMid:17617483.

Grigore-Gurgu, L., Bucur, F. I., Borda, D., Alexa, E.-A., Neagu, C., \& Nicolau, A. I. (2019). Biofilms formed by pathogens in food and food processing environments. In S. Dincer, M. Sümengen Özdenefe \& A. Arkut (Eds), Bacterial biofilms. London: IntechOpen. http:// dx.doi.org/10.5772/intechopen.90176.

Habbadi, K., Meyer, T., Vial, L., Gaillard, V., Benkirane, R., Benbouazza, A., Kerzaon, I., Achbani, E. H., \& Lavire, C. (2018). Essential oils of Origanum compactum and Thymus vulgaris exert a protective effect against the phytopathogen Allorhizobium vitis. Environmental Science and Pollution Research International, 25(30), 29943-29952. http:// dx.doi.org/10.1007/s11356-017-1008-9. PMid:29288304.

Hajimonfarednejad, M., Nimrouzi, M., Heydari, M., Zarshenas, M. M., Raee, M. J., \& Jahromi, B. N. (2018). Insulin resistance improvement by cinnamon powder in polycystic ovary syndrome: a randomized double-blind placebo controlled clinical trial. Phytotherapy Research, 32(2), 276-283. http://dx.doi.org/10.1002/ptr.5970. PMid:29250843.

Hamed, I., Ozogul, F., Ozogul, Y., \& Regenstein, J. M. (2015). Marine bioactive compounds and their health benefits: a review. Comprehensive Reviews in Food Science and Food Safety, 14(4), 446-465. http:// dx.doi.org/10.1111/1541-4337.12136.

Hashemi, S. M. B., Khaneghah, A. M., \& de Souza Sant'Ana, A. (2017). Essential oils in food processing: chemistry, safety and applications. West Sussex: Wiley-Blackwell. http://dx.doi.org/10.1002/9781119149392.

Hasler, C. M. (2002). Functional foods: benefits, concerns and challenges-a position paper from the American Council on Science and Health. The Journal of Nutrition, 132(12), 3772-3781. http:// dx.doi.org/10.1093/jn/132.12.3772. PMid:12468622. 
Hu, Y., Zhang, J., Kong, W., Zhao, G., \& Yang, M. (2017). Mechanisms of antifungal and anti-aflatoxigenic properties of essential oil derived from turmeric (Curcuma longa L.) on Aspergillus flavus. Food Chemistry, 220, 1-8. http://dx.doi.org/10.1016/j.foodchem.2016.09.179. PMid:27855875.

Hygreeva, D., Pandey, M., \& Radhakrishna, K. (2014). Potential applications of plant-based derivatives as fat replacers, antioxidants and antimicrobials in fresh and processed meat products. Meat Science, 98(1), 47-57. http://dx.doi.org/10.1016/j.meatsci.2014.04.006. PMid:24845336.

Hyldgaard, M., Mygind, T., \& Meyer, R. L. (2012). Essential oils in food preservation: mode of action, synergies, and interactions with food matrix components. Frontiers in Microbiology, 3, 12. http://dx.doi. org/10.3389/fmicb.2012.00012. PMid:22291693.

Ieven, M., Vlietinck, A. J., Vanden Berghe, D. A., Totte, J., Dommisse, R., Esmans, E., \& Alderweireldt, F. (1982). Plant antiviral agents. III. Isolation of alkaloids from Clivia miniata Regel (Amaryl-lidaceae). Journal of Natural Products, 45(5), 564-573. http://dx.doi.org/10.1021/ np50023a009. PMid:7153775.

Jamshidi-Kia, F., Lorigooini, Z., \& Amini-Khoei, H. (2018). Medicinal plants: past history and future perspective. Journal of HerbMed Pharmacology, 7(1), 1-7. http://dx.doi.org/10.15171/jhp.2018.01.

Jayasena, D., \& Jo, C. (2013). Essential oils as potential antimicrobial agents in meat and meat products: a review. Trends in Food Science \& Technology, 34(2), 96-108. http://dx.doi.org/10.1016/j.tifs.2013.09.002.

Jensen, S. K., \& Nielsen, K. N. (1996). Tocopherols, retinol, b-carotene and fatty acids in fat globule membrane and fat globule core in cows' milk. The Journal of Dairy Research, 63(4), 565-574. http://dx.doi. org/10.1017/S0022029900032106. PMid:8933307.

Juneja, V. K., Dwivedi, H. P., \& Yan, X. (2012). Novel natural food antimicrobials. Annual Review of Food Science and Technology, 3, 381-403. http://dx.doi.org/10.1146/annurev-food-022811-101241. PMid:22385168.

Kang, J., Liu, L., Wu, X., Sun, Y., \& Liu, Z. (2018). Effect of thyme essential oil against Bacillus cereus planktonic growth and biofilm formation. Applied Microbiology and Biotechnology, 102(23), 1020910218. http://dx.doi.org/10.1007/s00253-018-9401-y. PMid:30288586.

Karre, L., Lopez, K., \& Getty, K. J. (2013). Natural antioxidants in meat and poultry products. Meat Science, 94(2), 220-227. http://dx.doi. org/10.1016/j.meatsci.2013.01.007. PMid:23501254.

Kelber, O., Bauer, R., \& Kubelka, W. (2017). Phytotherapy in functional gastrointestinal disorders. Digestive Diseases and Sciences, 35(Suppl. 1), 36-42. http://dx.doi.org/10.1159/000485489. PMid:29421793.

Kerekes, E. B., Vidács, A., Török Jenei, J., Gömöri, C., Takó, M., Muthusamy, C., Kadaikunnan, S., Alharbi, N. S., Krisch, J., \& Vágvölgyi, C. (2015). Essential oils against bacterial biofilm formation and quorum sensing of food-borne pathogens and spoilage microorganisms. In A. Méndez-Vilas (Ed.) The battle against microbial pathogens: basic science, technological advances and educational programs (pp. 429-437). Bajadoz: Formatex Research Center.

Khan, I. T., Nadeem, M., Imran, M., Ullah, M., Ajmal, R., \& Jaspal, M. H. (2019). Antioxidant properties of milk and dairy products: a comprehensive review of the current knowledge. Lipids in Health and Disease, 18(1), 41. http://dx.doi.org/10.1186/s12944-019-09698. PMid:30717735.

Khezerlou, A., \& Jafari, S. M. (2020). Nanoencapsulated bioactive components for active food packaging. In: S. M. Jafari (Ed.), Handbook offood nanotechnology (pp. 493-532). Amsterdam: Academic Press. http://dx.doi.org/10.1016/B978-0-12-815866-1.00013-3.
Kim, S. J., Cho, A. R., \& Han, J. (2013). Antioxidant and antimicrobial activities of leafy green vegetable extracts and their applications to meat product preservation. Food Control, 29(1), 112-120. http:// dx.doi.org/10.1016/j.foodcont.2012.05.060.

Koutroumanidou, E., Kimbaris, A., Kortsaris, A., Bezirtzoglou, E., Polissiou, M., Charalabopoulos, K., \& Pagonopoulou, O. (2013). Increased seizure latency and decreased severity of pentylenetetrazol-induced seizures in mice after essential oil administration. Epilepsy Research and Treatment, 2013, 532657. http://dx.doi.org/10.1155/2013/532657. PMid:23819045.

Kuropka, G., Neugebauer, M., \& Glombitza, K. W. (1991). Essential oils of Achillea ptarmica. Planta Medica, 57(5), 492-494. http://dx.doi. org/10.1055/s-2006-960180. PMid:17226187.

Laranjo, M., Fernández-León, A. M., Agulheiro-Santos, A. C., Potes, M. E., \& Elias, M. (2019). Essential oils of aromatic and medicinal plants play a role in food safety. Journal of Food Processing and Preservation, 00, e14278. http://dx.doi.org/10.1111/jfpp.14278.

Laranjo, M., Fernández-Léon, A. M., Potes, M. E., Agulheiro-Santos, A. C., \& Elias, M. (2017). Use of essential oils in food preservation. In A. Méndez-Vilas (Ed.), Antimicrobial research: novel bioknowledge and educational programs (pp. 177-188). Badajoz: Formatex Research Center.

Leonard, C. M., Virijevic, S., Regnier, T., \& Combrinck, S. (2010). Bioactivity of selected essential oils and some components on Listeria monocytogenes biofilms. South African Journal of Botany, 76(4), 676-680. http://dx.doi.org/10.1016/j.sajb.2010.07.002.

Li, Y.-Q., Kong, D.-X., Huang, R.-S., Liang, H.-L., Xu, C.-G., \& Wu, G. (2013). Variations in essential oil yields and compositions of Cinnamomum cassia leaves at different developmental stages. Industrial Crops and Products, 47, 92-101. http://dx.doi.org/10.1016/j. indcrop.2013.02.031.

Lin, L., Zhu, Y., \& Cui, H. (2018). Electrospun thyme essential oil/ gelatin nanofibers for active packaging against Campylobacter jejuni in chicken. Lebensmittel-Wissenschaft + Technologie, 97, 711-718. http://dx.doi.org/10.1016/j.lwt.2018.08.015.

Lorenzo, J. M., Khaneghah, A. M., Gavahian, M., Marszałek, K., Es, I., Munekata, P. E. S., Ferreira, F. R. I. C., \& Barba, F. J. (2019). Understanding the potential benefits of thyme and its derived products for food industry and consumer health: From extraction of value-added compounds to the evaluation of bioaccessibility, bioavailability, anti-inflammatory, and antimicrobial activities. Critical Reviews in Food Science and Nutrition, 59(18), 2879-2895. http://dx.doi.org/10.1080/10408398.2018.1477730. PMid:29771598.

Lorenzo, J. M., Pateiro, M., Domínguez, R., Barba, F. J., Putnik, P., Kovačević, D. B., Shpigelman, A., Granato, D., \& Franco, D. (2018). Berries extracts as natural antioxidants in meat products: a review. Food Research International, 106, 1095-1104. http://dx.doi. org/10.1016/j.foodres.2017.12.005. PMid:29579903.

Lu, Y., \& Foo, Y. (2001). Antioxidant activities of polyphenols from sage (Salvia officinalis). Food Chemistry, 75(2), 197-202. http://dx.doi. org/10.1016/S0308-8146(01)00198-4.

Luciardi, M. C., Blázquez, M. A., Cartagena, E., Bardón, A., \& Arena, M. E. (2016). Mandarin essential oils inhibit quorum sensing and virulence factors of Pseudomonas aeruginosa. LebensmittelWissenschaft + Technologie, 68, 373-380. http://dx.doi.org/10.1016/j. lwt.2015.12.056.

Machado, I., Silva, L. R., Giaouris, E. D., Melo, L. F., \& Simões, M. (2020). Quorum sensing in food spoilage and natural-based strategies for its inhibition. Food Research International, 127, 108754. http://dx.doi. org/10.1016/j.foodres.2019.108754. PMid:31882100. 
Macho-González, A., Garcimartín, A., López-Oliva, M. E., Bastida, S., Benedí, J., Ros, G., Nieto, G., \& Sánchez-Muniz, F. J. (2020). Can meat and meat-products induce oxidative stress? Antioxidants, 9(7), 638. http://dx.doi.org/10.3390/antiox9070638. PMid:32698505.

Magnuson, B., Munro, I., Abbot, P., Baldwin, N., Lopez-Garcia, R., Ly, K., McGirr, L., Roberts, A., \& Socolovsky, S. (2013). Review of the regulation and safety assessment of food substances in various countries and jurisdictions. Food Additives \& Contaminants Part A, 30(7), 1147-1220. http://dx.doi.org/10.1080/19440049.2013.79 5293. PMid:23781843.

Mani-López, E., Palou, E., \& López-Malo, A. (2018). Biopreservatives as agents to prevent food spoilage. In A. M. Holban \& A. M. Grumezescu (Eds.), Microbial contamination and food degradation ( $1^{\text {st }}$ ed., pp. 235-270, Vol. 10). London: Academic Press. http://dx.doi. org/10.1016/B978-0-12-811515-2.00008-1.

Martillanes, S., Rocha-Pimienta, J., Cabrera-Bañegil, M., Martín-Vertedor, D., \& Delgado-Adámez, J. (2017). Application of phenolic compounds for food preservation: food additive and active packaging. In M. Soto-Hernández, P. M. Tenango \& M. del Rosario Garcia-Mateos (Eds.), Phenolic compounds: biological activity (pp. 39-58). Crotia: InTech. http://dx.doi.org/10.5772/66885.

Martínez-Tomé, M., Jiménez, A. M., Ruggieri, S., Frega, N., Strabbioli, R., \& Murcia, M. A. (2001). Antioxidant properties of Mediterranean spices compared with common food additives. Journal of Food Protection, 64(9), 1412-1419. http://dx.doi.org/10.4315/0362028X-64.9.1412. PMid:11563520.

Mehdizadeh, T., Hashemzadeh, M. S., Nazarizadeh, A., NeyrizNaghadehi, M., Tat, M., Ghalavand, M., \& Dorostkar, R. (2016). Chemical composition and antibacterial properties of Ocimum basilicum, Salvia officinalis and Trachyspermum ammi essential oils alone and in combination with nisin. Research Journal of Pharmacognosy, 3(4), 51-58.

Melo, R. S., Albuquerque Azevedo, Á. M., Gomes Pereira, A. M., Rocha, R. R., Bastos Cavalcante, R. M., Carneiro Matos, M. N., Ribeiro Lopes, P. H., Gomes, G. A., Soares Rodrigues, T. H., Santos, H. S. D., Ponte, I. L., Costa, R. A., Brito, G. S., Catunda, F. E. A., Jr. \& Carneiro, V. A. (2019). Chemical composition and antimicrobial effectiveness of Ocimum gratissimum L. essential oil against multidrug-resistant isolates of Staphylococcus aureus and Escherichia coli. Molecules, 24(21), 3864. http://dx.doi.org/10.3390/molecules24213864. PMid:31717766.

Miguel, M. G. (2010). Antioxidant and anti-inflammatory activities of essential oils: a short review. Molecules, 15(12), 9252-9287. http:// dx.doi.org/10.3390/molecules15129252. PMid:21160452.

Miller, M. B., \& Bassler, B. L. (2001). Quorum sensing in bacteria. Annual Review of Microbiology, 55(1), 165-199. http://dx.doi.org/10.1146/ annurev.micro.55.1.165. PMid:11544353.

Mimica-Dukić, N., Bozin, B., Soković, M., Mihajlović, B., \& Matavulj, M. (2003). Antimicrobial and antioxidant activities of three Mentha species essential oils. Planta Medica, 69(5), 413-419. http://dx.doi. org/10.1055/s-2003-39704. PMid:12802721.

Mishra, A. K., Sahu, N., Mishra, A., Ghosh, A. K., Jha, S., \& Chattopadhyay, P. (2010). Phytochemical screening and antioxidant activity of essential oil of Eucalyptus leaf. Pharmacognosy Journal, 2(16), 25-28. http://dx.doi.org/10.1016/S0975-3575(10)80045-8.

Mishra, A. P., Devkota, H. P., Nigam, M., Adetunji, C. O., Srivastava, N., Saklani, S., Shukla, I., Azmi, L., Shariati, M. A., Melo Coutinho, H. D., \& Khaneghah, A. M. (2020). Combination of essential oils in dairy products: a review of their functions and potential benefits. Lebensmittel-Wissenschaft + Technologie, 133, 110116. http://dx.doi. org/10.1016/j.lwt.2020.110116.
Mith, H., Dure, V., Delcenserie, V., Zhiri, A., Daube, A., \& Clinquart, A. (2014). Antimicrobial activities of commercial essential oils and their components against food-borne pathogens and food spoilage bacteria. Food Science \& Nutrition, 2(4), 403-416. http://dx.doi. org/10.1002/fsn3.116. PMid:25473498.

Mitić-Ćulafić, D., Vuković-Gačić, B. S., Knežević-Vukčević, J. B., Stanković, S., \& Simić, D. M. (2005). Comparative study on the antibacterial activity of volatiles from sage (Salvia officinalis L.). Archives of Biological Sciences, 57(3), 173-178. http://dx.doi. org/10.2298/ABS0503173M.

Mizan, M. F., Jahid, I. K., Kim, M., Lee, K. H., Kim, T. J., \& Ha, S. D. (2016). Variability in biofilm formation correlates with hydrophobicity and quorum sensing among Vibrio parahaemolyticus isolates from food contact surfaces and the distribution of the genes involved in biofilm formation. Biofouling, 32(4), 497-509. http://dx.doi.org/10 .1080/08927014.2016.1149571. PMid:26980068.

Mukherjee, S., \& Bassler, B. L. (2019). Bacterial quorum sensing in complex and dynamically changing environments. Nature Reviews. Microbiology, 17(6), 371-382. http://dx.doi.org/10.1038/s41579-0190186-5. PMid:30944413.

Nanditha, B., \& Prabhasankar, P. (2009). Antioxidants in bakery products: a review. Critical Reviews in Food Science and Nutrition, 49(1), 1-27. http://dx.doi.org/10.1080/10408390701764104. PMid:18949596.

Nazzaro, F., Fratianni, F., Coppola, R., \& Feo, V. (2017). Essential oils and antifungal activity. Pharmaceuticals, 10(4), 86. http://dx.doi. org/10.3390/ph10040086. PMid:29099084.

Nazzaro, F., Fratianni, F., de Martino, L., Coppola, R., \& de Feo, V. (2013). Effect of essential oils on pathogenic bacteria. Pharmaceuticals, 6(12), 1451-1474. http://dx.doi.org/10.3390/ph6121451. PMid:24287491.

Nielsen, J. H., Hald, G., Kjeldsen, L., Andersen, H. J., \& Østdal, H. (2001). Oxidation of ascorbate in raw milk induced by enzymes and transition metals. Journal of Agricultural and Food Chemistry, 49(6), 2998-3003. http://dx.doi.org/10.1021/jf000862j. PMid:11410000.

Niero, G., De Marchi, M., Masi, A., Penasa, M., \& Cassandro, M. (2015). Short communication: Characterization of soluble thiols in bovine milk. Journal of Dairy Science, 98(9), 6014-6017. http:// dx.doi.org/10.3168/jds.2015-9740. PMid:26188581.

Ningombam, A., Seileshkumar, T., Santhalembi, L., Singh, I., \& Prakash, N. (2017). Strategies and management practices for stored grain pest. In N. Prakash, S. Roy, M. Ansari, P. Punitha, S. Sharma, B. Sailo, R. Anandy \& M. Singhi (Eds.), Training manual-integrated farming system for sustainable hill agriculture: an option for climate smart agriculture and NRM. Imphal: ICAR Research Complex for Neh Region.

Notka, F., Meier, G., \& Wagner, R. (2004). Concerted inhibitory activities of Phyllanthus amarus on HIV replication in vitro and ex vivo. Antiviral Research, 64(2), 93-102. http://dx.doi.org/10.1016/ S0166-3542(04)00129-9. PMid:15498604.

Olivero, V. J. T., Pajaro, C., Nerlis, P., \& Stashenko, E. (2011). Antiquorum sensing activity of essentil oils isolated from different species of the genus Piper. Vitae, 18(1), 77-82.

Oniga, I., Pușcaș, C., Silaghi-Dumitrescu, R., Olah, N.-K., Sevastre, B., Marica, R., Marcus, I., Sevastre-Berghian, A. C., Benedec, D., Pop, C. E., \& Hanganu, D. (2018). Origanum vulgare ssp. vulgare: chemical composition and biological studies. Molecules, 23(8), 2077. http:// dx.doi.org/10.3390/molecules23082077. PMid:30126246.

Opalchenova, G., \& Obreshkova, D. (2003). Comparative studies on the activity of basil-an essential oil from Ocimum basilicum L. against multidrug resistant clinical isolates of the genera Staphylococcus, Enterococcus and Pseudomonas by using different test methods. 
Journal of Microbiological Methods, 54(1), 105-110. http://dx.doi. org/10.1016/S0167-7012(03)00012-5. PMid:12732427.

Ortega-Ramirez, L. A., Rodriguez-Garcia, I., Leyva, J. M., CruzValenzuela, M. R., Silva-Espinoza, B. A., Gonzalez-Aguilar, G. A., Siddiqui, M. W., \& Ayala-Zavala, J. F. (2014). Potential of medicinal plants as antimicrobial and antioxidant agents in food industry: a hypothesis. Journal of Food Science, 79(2), R129-R137. http://dx.doi. org/10.1111/1750-3841.12341. PMid:24446991.

Oswell, N. J., Thippareddi, H., \& Pegg, R. B. (2018). Practical use of natural antioxidants in meat products in the U.S.: a review. Meat Science, 145, 469-479. http://dx.doi.org/10.1016/j.meatsci.2018.07.020. PMid:30071458.

Papuc, C., Goran, G. V., Predescu, C. N., \& Nicorescu, V. (2017). Nicorescu, V. Mechanisms of oxidative processes in meat and toxicity induced by postprandial degradation products: a review. Comprehensive Reviews in Food Science and Food Safety, 16(1), 96123. http://dx.doi.org/10.1111/1541-4337.12241. PMid:33371549.

Pateiro, M., Barba, F. J., Domínguez, R., Sant'Ana, A. S., Khaneghah, A. M., Gavahian, M., Gómez, B., \& Lorenzo, J. M. (2018). Essential oils as natural additives to prevent oxidation reactions in meat and meat products: a review. Food Research International, 113, 156-166. http://dx.doi.org/10.1016/j.foodres.2018.07.014. PMid:30195508.

Pérez-Rodríguez, F., \& Mercanoglu Taban, B. (2019). A state-of-art review on multi-drug resistant pathogens in foods of animal origin: Risk factors and mitigation strategies. Frontiers in Microbiology, 10, 2091. http://dx.doi.org/10.3389/fmicb.2019.02091. PMid:31555256.

Poli, J.-P., Guinoiseau, E., de Rocca Serra, D., Sutour, S., Paoli, M., Tomi, F., Quilichini, Y., Berti, L., \& Lorenzi, V. (2018). Anti-quorum sensing activity of 12 essential oils on Chromobacterium violaceum and specific action of cis-cis-p-menthenolide from Corsican Mentha suaveolens spp. Insularis. Molecules, 23(9), 1-11. http://dx.doi. org/10.3390/molecules23092125. PMid:30142938.

Politeo, O., Jukić, M., \& Miloš, M. (2006). Chemical composition and antioxidant activity of essential oils of twelve spice plants. Croatica Chemica Acta, 79(4), 545-552.

Prakash, B., Kujur, A., Singh, P. P., Kumar, A., \& Yadav, A. (2017). Plantsderived bioactive compounds as functional food ingredients and food preservative. Journal of Nutrition \& Food Sciences, 1, 100004.

Prakash, B., Singh, P., Kedia, A., \& Dubey, N. K. (2012). Assessment of some essential oils as food preservatives based on antifungal, antiaflatoxin, antioxidant, activities and in vivo efficacy in food system. Food Research International, 49(1), 201-208. http://dx.doi. org/10.1016/j.foodres.2012.08.020.

Rašković, A., Milanović, I., Pavlović, N., Ćebović, T., Vukmirović, S., \& Mikov, M. (2014). Antioxidant activity of rosemary (Rosmarinus officinalis L.) essential oil and its hepatoprotective potential. BMC Complementary and Alternative Medicine, 14(1), 225. http://dx.doi. org/10.1186/1472-6882-14-225. PMid:25002023.

Raut, J. S., \& Karuppayil, S. M. (2014). A status review on the medicinal properties of essential oils. Industrial Crops and Products, 62, 250264. http://dx.doi.org/10.1016/j.indcrop.2014.05.055.

Renard-Nozaki, J., Kim, T., Imakura, Y., Kihara, M., \& Kobayashi, S. (1989). Effect of alkaloids isolated from Amaryllidaceae on herpes simplex virus. Research in Virology, 140(2), 115-128. http://dx.doi. org/10.1016/S0923-2516(89)80089-5. PMid:2547235.

Ribeiro-Santos, R., Andrade, M., Melo, N. R., \& Sanches-Silva, A. (2017). Use of essential oils in active food packaging: recent advances and future trends. Trends in Food Science \& Technology, 61, 132-140. http://dx.doi.org/10.1016/j.tifs.2016.11.021.
Ribeiro-Santos, R., Carvalho-Costa, D., Cavaleiro, C., Costa, H. S., Albuquerque, T. G., Castilho, M. C., Ramos, F., Melo, N. R., \& Sanches-Silva, A. (2015). A novel insight on an ancient aromatic plant: the rosemary (Rosmarinus officinalis L.). Trends in Food Science \& Technology, 45(2), 355-368. http://dx.doi.org/10.1016/j. tifs.2015.07.015.

Ruberto, G., \& Baratta, M. T. (2000). Antioxidant activity of selected essential oil components in two lipid model systems. Food Chemistry, 69(2), 167-174. http://dx.doi.org/10.1016/S0308-8146(99)00247-2.

Salgado, P. R., Di Giorgio, L., Musso, Y. S., \& Mauri, A. N. (2019). Bioactive packaging: Combining nanotechnologies with packaging for improved food functionality. In A. López Rubio, M. J. Fabra Rovira, M. Martínez Sanz \& L. G. Gómez-Mascaraque (Eds.), Nanomaterials for food applications (pp. 233-270). Amsterdam: Elsevier. http://dx.doi.org/10.1016/B978-0-12-814130-4.00009-9.

Sartoratto, A., Machado, A. L. M., Delarmelina, C., Figueira, G. M., Duarte, M. C. T., \& Rehder, V. L. G. (2004). Composition and antimicrobial activity of essential oils from aromatic plants used in Brazil. Brazilian Journal of Microbiology, 35(4), 275-280. http:// dx.doi.org/10.1590/S1517-83822004000300001.

Schilcher, H., Kammerer, S., \& Wegener, T. (2016). Leitfaden Phytotherapie, 3. Auflage Leitfaden Phytotherapie. München: Elsevier GmbH. Retrieved from http: www.unimedica.de/b9665

Sebei, K., Sakouhi, F., Herchi, W., Khouja, M. L., \& Boukhchina, S. (2015). Chemical composition and antibacterial activities of seven Eucalyptus species essential oils leaves. Biological Research, 48(1), 7. http://dx.doi.org/10.1186/0717-6287-48-7. PMid:25654423.

Settanni, L., Palazzolo, E., Guarrasi, V., Aleo, A., Mammina, C., Moschetti, G., \& Germanà, M. A. (2012). Inhibition of foodborne pathogen bacteria by essential oils extracted from citrus fruits cultivated in Sicily. Food Control, 26(2), 326-330. http://dx.doi.org/10.1016/j. foodcont.2012.01.050.

Shah, M., Don Bosco, S., \& Mir, S. (2014). Plant extracts as natural antioxidants in meat and meat products. Meat Science, 98(1), 21-33. http://dx.doi.org/10.1016/j.meatsci.2014.03.020. PMid:24824531.

Shahidi, F., \& Ambigaipalan, P. (2015). Phenolics and polyphenolics in foods, beverages and spices: antioxidant activity and health effects: a review. Journal of Functional Foods, 18, 820-897. http://dx.doi. org/10.1016/j.jff.2015.06.018.

Sharma, P., Kumar, P., Sharma, R., Gupta, G., \& Chaudhary, A. (2017). Immunomodulators: role of medicinal plants in immune system. National Journal of Physiology, Pharmacy and Pharmacology, 7(6), 551-556. http://dx.doi.org/10.5455/njppp.2017.7.0203808032017.

Sharma, S., Barkauskaite, S., Jaiswal, A. K., \& Jaiswal, S. (2021). Essential oils as additives in active food packaging. Food Chemistry, 343, 128403. http://dx.doi.org/10.1016/j.foodchem.2020.128403. PMid:33268167.

Sharopov, F., Braun, M. S., Gulmurodov, I., Khalifaev, D., Isupov, S., \& Wink, M. (2015). Antimicrobial, antioxidant, and anti-inflammatory activities of essential oils of selected aromatic plants from Tajikistan. Foods, 4(4), 645-653. http://dx.doi.org/10.3390/foods4040645. PMid:28231227.

Silva, S., Alves, N., Silva, P., Vieira, T., Maciel, P., Castellano, L. R., Bonan, P., Velozo, C., \& Albuquerque, D. (2019). Antibacterial activity of Rosmarinus officinalis, Zingiber officinale, Citrus aurantium bergamia, and Copaifera officinalis alone and in combination with calcium hydroxide against Enterococcus faecalis. BioMed Research International, 2019, 8129439. http://dx.doi.org/10.1155/2019/8129439.

Singh Negi, P. (2012). Plant extracts for the control of bacterial growth: Efficacy, stability and safety issues for food application. International Journal of Food Microbiology, 156(1), 7-17. http://dx.doi.org/10.1016/j. ijfoodmicro.2012.03.006. PMid:22459761. 
Singh, R., Shushni, M. A. M., \& Belkheir, A. (2015). Antibacterial and antioxidant activities of Mentha piperita L. Arabian Journal of Chemistry, 8(3), 322-328. http://dx.doi.org/10.1016/j.arabjc.2011.01.019.

Singh, V. P. (2018). Recent approaches in food bio-preservation: a review. Open Veterinary Journal, 8(1), 104-111. http://dx.doi.org/10.4314/ ovj.v8i1.16. PMid:29721439.

Siramon, P., \& Ohtani, Y. (2007). Antioxidative and antiradical activities of Eucalyptus camaldulensis leaf oils from Thailand. Journal of Wood Science, 53(6), 498-504. http://dx.doi.org/10.1007/s10086-007-0887-7.

Sirocchi, V., Caprioli, G., Cecchini, C., Coman, M. M., Cresci, A., Maggi, F., Papa, F., Ricciutelli, M., Vittori, S., \& Sagratini, G. (2013). Biogenic amines as freshness index of meat wrapped in a new active packaging system formulated with essential oils of Rosmarinus officinalis. International Journal of Food Sciences and Nutrition, 64(8), 921-928. http://dx.doi.org/10.3109/09637486.2013.809706 PMid:23815565.

Smid, E. J., \& Gorris, L. G. M. (1999). Natural antimicrobials for food preservation. In M. S. Rahman (Ed.), Handbook of food preservation (pp. 285-308). New York: Marcel Dekker.

Socaci, S. A., Fărcaş, A. C., \& Tofană, M. (2020). Functional ingredients derived from aromatic plants. In P Florou-Paneri, E Christaki, \& I Giannenas (Eds.), Feed additives (pp. 133-146). London: Academic Press. http://dx.doi.org/10.1016/B978-0-12-814700-9.00008-X.

Solórzano-Santos, F., \& Miranda-Novales, M. G. (2012). Essential oils from aromatic herbs as antimicrobial agents. Current Opinion in Biotechnology, 23(2), 136-141. http://dx.doi.org/10.1016/j. copbio.2011.08.005. PMid:21903378.

Stanojević, L. P., Stanojević, J. S., Cvetković, D. J., \& Ilić, D. P. (2016). Antioxidant activity of oregano essential oil (Origanum vulgare L.). Biologica Nyssana, 7(2), 131-139. http://dx.doi.org/10.5281/ zenodo. 200410 .

Suppakul, P., Miltz, J., Sonneveld, K., \& Bigger, S. W. (2003). Active packaging technologies with an emphasis on antimicrobial packaging and its applications. Journal of Food Science, 68(2), 408-420. http:// dx.doi.org/10.1111/j.1365-2621.2003.tb05687.x.

Suppakul, P., Sonneveld, K., Bigger, S. W., \& Miltz, J. (2008). Efficacy of polyethylene-based antimicrobial films containing principal constituents of basil. Lebensmittel-Wissenschaft + Technologie, 41(5), 779-788. http://dx.doi.org/10.1016/j.lwt.2007.06.006.

Szczepanski, S., \& Lipski, A. (2014). Essential oils show specific inhibiting effects on bacterial biofilm formation. Food Control, 36(1), 224-229. http://dx.doi.org/10.1016/j.foodcont.2013.08.023.

Tariq, S., Wani, S., Rasool, W., Shafi, K., Bhat, M. A., Prabhakar, A., Shalla, A. H., \& Rather, M. A. (2019). A comprehensive review of the antibacterial, antifungal and antiviral potential of essential oils and their chemical constituents against drug-resistant microbial pathogens. Microbial Pathogenesis, 134, 103580. http://dx.doi. org/10.1016/j.micpath.2019.103580. PMid:31195112.

Teixeira, B., Marques, A., Ramos, C., Neng, N. R., Nogueira, J. M. F., Saraiva, J. A., \& Nunes, M. L. (2013). Chemical composition and antibacterial and antioxidant properties of commercial essential oils. Industrial Crops and Products, 43, 587-595. http://dx.doi. org/10.1016/j.indcrop.2012.07.069.

Tirado, C. B., Stashenko, E. E., Combariza, M. Y., \& Martinez, J. R. (1995). Comparative study of Colombian citrus oils by high-resolution gas chromatography and gas chromatography-mass spectrometry. Journal of Chromatography. A, 697(1-2), 501-513. http://dx.doi. org/10.1016/0021-9673(94)00955-9.

Tohma, S., \& Turan, S. (2015). Rosemary plant (Rosmarinus officinalis 1.), solvent extract and essential oil can be used to extend the usage life of hazelnut oil during deep frying. European Journal of Lipid Science and Technology, 117(12), 1978-1990. http://dx.doi. org/10.1002/ejlt.201400382.

Tongnuanchan, P., \& Benjakul, S. (2014). Essential oils: Extraction, bioactivities, and their uses for food preservation. Journal of Food Science, 79(7), R1231-R1249. http://dx.doi.org/10.1111/17503841.12492. PMid:24888440.

Trombetta, D., Castelli, F., Sarpietro, M. G., Venuti, V., Cristani, M., Daniele, C., Saija, A., Mazzanti, G., \& Bisignano, G. (2005). Mechanisms of antibacterial action of three monoterpenes. Antimicrobial Agents and Chemotherapy, 49(6), 2474-2478. http://dx.doi.org/10.1128/ AAC.49.6.2474-2478.2005. PMid:15917549.

U.S. Food and Drug Administration - FDA. (2016). Code of federal regulations (CFR). Title 21: Food and drugs. Chapter I - food and drug administration, department of health and human services, subchapter B - food for human consumption (continued), Part 182 substances generally recognized as safe (GRAS), subpart a - general provisions, subpart 182.20 - essential oils, oleoresins, and natural extractives. Washington: Office of the Federal Register. Retrieved from https://www.accessdata.fda.gov/scripts/cdrh/cfdocs/cfcfr/ CFRSearch.cfm?fr $=182.20$

Unlu, M., Ergene, E., Unlu, G. V., Zeytinoglu, H. S., \& Vural, N. (2010). Composition, antimicrobial activity and in vitro cytotoxicity of essential oil from Cinnamomum zeylanicum Blume (Lauraceae). Food and Chemical Toxicology, 48(11), 3274-3280. http://dx.doi. org/10.1016/j.fct.2010.09.001. PMid:20828600.

Vilela, C., Kurek, M., Hayouka, Z., Röcker, B., Yildirim, S., Antunes, M. D. C., Nilsen-Nygaard, J., Pettersen, M. K., \& Freire, C. S. R. (2018). A concise guide to active agents for active food packaging. Trends in Food Science \& Technology, 80, 212-222. http://dx.doi. org/10.1016/j.tifs.2018.08.006.

Wadood, A., Ghufran, M., Jamal, S. B., Naeem, M., Khan, A., \& Ghaffar, R. (2013). Phytochemical analysis of medicinal plants occurring in local area of Mardan. Biochemistry and Analytical Biochemistry, 2(4), 4. http://dx.doi.org/10.4172/2161-1009.1000144.

Wen, P., Zhu, D.-H., Wu, H., Zong, M.-H., Jing, Y.-R., \& Han, S.-Y. (2016). Encapsulation of cinnamon essential oil in electrospun nanofibrous film for active food packaging. Food Control, 59, 366376. http://dx.doi.org/10.1016/j.foodcont.2015.06.005.

World Health Organization - WHO. (2020). Obesity and overweight. Geneva: WHO. Retrieved from https://www.who.int/en/news-room/ fact-sheets/detail/obesity-and-overweight

Yasmin, A. R., Chia, S. L., Looi, Q. H., Omar, A. R., Noordin, M. M., \& Ideris, A. (2020). Herbal extracts as antiviral agents. In P Florou-Paneri, E Christaki, \& I Giannenas (Eds.), Feed additives (pp. 115-137). London: Academic Press. http://dx.doi.org/10.1016/ B978-0-12-814700-9.00007-8.

Zerghad, N., \& Merghem, R. (2013). Antioxidant and antibacterial activities of Thymus vulgaris L. Romanian Journal of Biology-Plant Biology, 58(1), 27-36. 